\title{
Origins of the Human Predatory Pattern The Transition to Large-Animal Exploitation by Early Hominins
}

\author{
by Jessica C. Thompson, Susana Carvalho, Curtis W. Marean, \\ and Zeresenay Alemseged
}

Online enhancements: supplemental appendix

\begin{abstract}
The habitual consumption of large-animal resources (e.g., similar sized or larger than the consumer) separates human and nonhuman primate behavior. Flaked stone tool use, another important hominin behavior, is often portrayed as being functionally related to this by the necessity of a sharp edge for cutting animal tissue. However, most research on both issues emphasizes sites that postdate ca. 2.0 million years ago. This paper critically examines the theoretical significance of the earlier origins of these two behaviors, their proposed interrelationship, and the nature of the empirical record. We argue that concepts of meat-eating and tool use are too loosely defined: outside-bone nutrients (e.g., meat) and inside-bone nutrients (e.g., marrow and brains) have different macronutrient characteristics (protein vs. fat), mechanical requirements for access (cutting vs. percussion), search, handling and competitive costs, encounter rates, and net returns. Thus, they would have demanded distinct technological and behavioral solutions. We propose that the regular exploitation of large-animal resources - the "human predatory pattern" - began with an emphasis on percussionbased scavenging of inside-bone nutrients, independent of the emergence of flaked stone tool use. This leads to a series of empirical test implications that differ from previous "meat-eating" origins scenarios.
\end{abstract}

Many primates consume animal resources, but humans are the only living primates that regularly exploit animals the same body size or larger than themselves (Butynski 1982). ${ }^{1}$ Although this behavior may have been present in some extinct hominins, we term this the "human predatory pattern" (HPP). This specifically separates the behavior from that of other living primates while remaining neutral about when and how it began and how such resources were actually acquired. Within paleoanthropology, the exploitation of larger animals has traditionally fallen under the umbrella term "meat-eating" (Stan-

Jessica C. Thompson is Assistant Professor in the Department of Anthropology at Yale University (10 Sachem Street, New Haven, Connecticut, 06511, USA [jessica.thompson@yale.edu]). Susana Carvalho is Assistant Professor in the Institute of Cognitive and Evolutionary Anthropology at the University of Oxford (64 Banbury Road, Oxford OX2 6PN, United Kingdom) and Director of Paleontology and Primatology at Gorongosa Restoration Project, Gorongosa National Park, Mozambique. Curtis W. Marean is Professor in the School of Human Evolution and Social Change and Institute of Human Origins of the Arizona State University (PO Box 874101, Tempe, Arizona 85287-4101, USA) and Honorary Professor at the Centre for Coastal Palaeoscience of the Nelson Mandela Metropolitan University (Port Elizabeth, Eastern Cape 6031, South Africa). Zeresenay Alemseged is Professor in the Department of Organismal Biology and Anatomy of the University of Chicago (1027 East 57th Street, Chicago, Illinois 60637, USA). This paper was submitted 27 IX 16, accepted 4 X 17, and electronically published 5 II 19. ford and Bunn 2001). Large animals represent concentrated packages of easily digestible and calorically rich fat and protein. Thus, they are often described as part of the high-quality diet necessary for major biological changes such as the larger brains and bodies of some early Pleistocene hominins (Antón, Potts, and Aiello 2014). However, even scavenging meat from largeanimal carcasses comes with significant costs in terms of predator exposure, bacteria load, and chewing energetics (Smith et al. 2015; Treves and Naughton-Treves 1999; Zink and Lieberman 2016). Dietary quality can be enhanced through consumption of alternative fat and protein sources (e.g., insects and small prey) or through premasticatory processing of foods that may or may not be animal derived (Carmody and Wrangham 2009; Hardy et al. 2015; Rothman et al. 2014). Thus, there is a need to critically examine the concept of meat-eating as it has been used in paleoanthropology and, specifically, to understand the evolutionary context of the emergence of the HPP as a behavior unique to the hominin lineage.

\section{Background}

For Dart (1953), the violent act of prey acquisition made meateating a fundamental milestone in human evolution. He argued

1. Because this paper draws on many different bodies of research, intext citations have been limited to the most relevant and/or recent works. For a more comprehensive citation list, refer to the online appendix. 
via his osteodontokeratic hypothesis that australopith carnivory in South Africa marked the "predatory transition from ape to man.” Subsequent taphonomic work by Brain (1981) revealed that accumulations of broken animal bones in South African caves did not represent the remains of australopith meals. Concepts of "humanness" and "meat-eating" continued their entanglement, however, with the naming of Homo habilis (the "handyman"), from East Africa, in 1964. Unlike Australopithecus, this hominin was associated with both stone tools and fossil animal bones, and the tool-use/meat-eating package became inherent parts of the definition of our genus Homo.

As in South Africa, critical assessment of these fossil and artifact accumulations resulted in the understanding that these sites were not the sole residues of hominin activities (Binford 1981). This research led to a voluminous and ongoing debate about the mode of early hominin carcass acquisition, and whether it was predominately through hunting or scavenging (Domínguez-Rodrigo et al. 2014; Pante et al. 2015). This debate has centered on localities in Olduvai Gorge, Tanzania, and other sites dating maximally to ca. 2.0 million years ago (2.0 Ma; Domínguez-Rodrigo, Barba, and Egeland 2007), and follows a general pattern in the literature in which meat-eating has been given most attention in the context of the behavioral and biological evolution of Homo (Bunn 2007).

Many of the presumed defining characteristics of later Homo are explicable in terms of energetic trade-offs involving dietary change. These include dentognathic transformations, encephalization, enhanced cooperation with nonkin, and life histories that include prolonged childhood, female postreproductive periods, and shorter interbirth intervals (Antón et al. 2014). The energetic cost of these changes would have been paid through consumption of higher quality foods, new processing methods for existing foods, food sharing, or other partnerships that reduced individual energetic costs (Gettler 2010). By 1.5 Ma, many of these characteristics had coalesced into a successful adaptive suite that would continue into later hominin evolution, arguably with roots fueled by earlier dietary change.

However, understanding the origins of meat-eating is a separate issue from its later evolutionary ramifications. Less effort has been put to exploring the initial transition to obligate omnivory, and most has relied on models derived from living ape ecology, especially chimpanzees (Stanford 1996). DomínguezRodrigo and Pickering (2017) argue that "it is most parsimonious to consider this shared behavioural module as a synapomorphy, rather than a homoplasy, of these sister taxa" (11), but they do not differentiate between body sizes or nutritional components (e.g., meat vs. fat) of prey. This approach has been applied as far back in time as Ardipithecus, ca. $4.4 \mathrm{Ma}$, by interpreting them as herbivores that opportunistically ate meat (Stanford 2012). Tappen (2001) also suggests that "early australopithecines may be expected to eat meat at least to the degree that living chimpanzees do (by argument from phylogeny and parsimony)" (14). Because of the lack of flaked stone tools from this time period, Stanford (2012) decouples meat-eating from stone tool use through analogy, inferring that "it is likely that they acquired prey in much the same manner as that employed by modern chimpanzees, i.e., capturing it by hand on the ground or in trees" (145).

The use of these chimpanzee models makes several assumptions about early hominin diet: (1) there is a long history of animal resource exploitation and dietary flexibility, (2) there was a focus on small prey before moving to larger prey, (3) most prey was cooperatively hunted, and (4) animal resources formed a small but persistent dietary element. The implication from this model is that the transition to the HPP occurred through expansion of existing omnivory to also include larger prey, drawing on existing cooperative hunting behavior and augmented by new emphasis on tool use. Regardless of inferred mode of acquisition (e.g., hunting, passive scavenging, or confrontational scavenging), this work is always undertaken with the assumption that large-animal resources offered benefits that outweighed their costs to later Homo but not to earlier hominins such as Australopithecus (Stanford and Bunn 2001). Here, we critique the model under which large-animal exploitation emerges as an extension of cooperative hunting of small prey and suggest an alternative hypothesis for the initial transition to the HPP. We argue that Pliocene hominins began their trajectory toward the HPP by exploiting mainly the inside-bone nutrients of large-animal carcasses using percussion technology_ but not necessarily flaked stone tools.

This paper has three goals. We examine the Pliocene hominin record beyond the earliest date for Homo at $2.8 \mathrm{Ma}$, where hominins such as Australopithecus exhibit a brain size that is $\sim 30 \%$ larger than a chimpanzee of comparable body size, canine size reduction, a significant degree of terrestriality, and a hand that shows adaptations for tool use (Kimbel and Villmoare 2016). We also reject further use of the term meat-eating, as it prioritizes outside-bone nutrients (meat) at the expense of inside-bone nutrients (e.g., the fat in brains and marrow). These have different macronutrient characteristics; mechanical requirements for access, search, competition, and handling costs; encounter rates; and net returns that would have demanded distinct technological and behavioral solutions. Similarly, although small mammals and reptiles, birds, fish, and insects do provide proteins and fats, and are therefore often treated under the rubric of "animal resources" (Lupo 2012), they also differ from large animals in their foraging costs. Therefore, here we investigate the origins of the HPP specifically, rather than meat-eating broadly construed.

\section{Ecology of Ape Omnivory and Use of the Chimpanzee Model}

Both of our closest living relatives - chimpanzees (Pan troglodytes) and bonobos (Pan paniscus) - hunt, but never for prey larger than themselves. Small ungulates such as duiker (Tribe Cephalophini) are one of the most commonly taken prey by bonobos (Surbeck and Hohmann 2008), whereas small-bodied 
primates represent the majority of vertebrate prey for chimpanzees (Watts and Mitani 2002). This shared pursuit of animal resources has led to the inference that a basic need or desire for them should have also been present in our last common ancestor and persisted throughout subsequent hominin evolution (McGrew 2010). The reconstruction of early hominins taking small prey and later transitioning to larger prey (or scavengable carcasses) also stems from analogy to living apes (Stanford 2001). However, their cooperative hunts rely on biological adaptations for moving quickly through tree canopies or (less frequently) on the ground and using sharp canines to dispatch prey (Stanford 1995).

For both bonobos and chimpanzees, higher-ranking individuals more frequently consume animal protein — even though it does not provide a large caloric contribution (Tennie, O'Malley, and Gilby 2014). In spite of the attraction of animal resources, chimpanzees are reluctant to scavenge (Watts 2008), and they do not take some low-cost hunting opportunities such as monitor lizards (Varanus spp.; McGrew 2015). This indicates that hunting of some small- and medium-bodied prey does not automatically translate into a universal motivation to exploit any available animals.

Although small prey may be less dangerous than large prey, many are fast moving, and thus energetically costly in the absence of biological adaptations for pursuit and capture. In the case of forest-dwelling animals, this often also requires a high degree of arboreality. Size of prey is an important correlate for group size and cooperative hunting even within the same species of ape; chimpanzees in Fongoli hunt nocturnal primates with tools (small prey, no cooperative hunting), in Bossou they eat tree pangolin (Phataginus tricuspis; small prey, no cooperative hunting), and in Gombe they hunt colobus monkeys (Colobus and Procolobus), a larger prey for which cooperative hunting is required. Such variability in response to local ecology might also be inferred for early hominins, such that some small terrestrial game may have been hunted in a manner analogous to apes. However, such resources differ in key ways from large animals, and thus occasional omnivory of small terrestrial animals in forested settings does not provide an obvious bridge to the exploitation of large animals in the mosaic habitats inhabited by early hominins, particularly Australopithecus.

For highly terrestrial modern hunter-gatherers, small prey are rarely taken unless investment is made in specific and often elaborate technology to facilitate their capture (Ugan 2005). In addition to being difficult to acquire, small prey are not easily shared. Smaller-bodied animals also lack the large fat reservoirs of brain and marrow present in larger animals (Speth 1989). Thus, increasing terrestriality without complex technology would have increased the cost of small, mobile prey relative to larger or less mobile options.

Although Domínguez-Rodrigo and Pickering (2017) summarize examples in which apes hunt small prey that are not fast moving, the majority of chimpanzee and bonobo hunts occur in this way. Although our shared desire for animal re- sources may be homologous, there is little phylogenetic basis for considering that the specific form of prey acquisition and processing observed in modern chimpanzees is a suitable model for early hominins. It is equally plausible that this behavior is a derived trait for chimpanzees, which is a common problem with ape analogies (Sayers and Lovejoy 2014). The key inference is that a long precedent of cooperative hunting of small prey as a main mode of acquisition was unlikely to have been a necessary or even likely preadaptation for hominins to begin exploiting large-bodied animals.

\section{Behavioral Ecological Approaches to Understanding the HPP}

The principles of optimal foraging theory provide a useful framework for examining the subsistence decisions of early hominins. Specifically, the diet breadth model allows for the development of predictions about the conditions under which a novel resource (e.g., large animals) would have been added to the existing dietary repertoire. Food items are ranked on their net return, enabling prediction of an optimal diet breadth (list of prey that are always pursued upon encounter). The currency of choice is normally calories, although macro- and micronutrient composition can also influence prey ranking (Hill 1988).

Costs are typically divided into search and handling costs (Codding and Bird 2015). The highest-ranking foods should always be taken on encounter, whereas lower-ranking foods may be bypassed, even if abundant, to continue pursuit of higherranking items. When something changes about the ecology or abundance of the forager, the novel resource, or other higherranked resources in the environment, then there may be expansions or contractions in dietary breadth. Significant changes in technology or social behavior can change prey costs, resulting in a change in its rank and thus its pursuit probability upon encounter.

The origins of the HPP can be conceptualized in terms of the costs and returns associated with prey and prey body parts, as well as those resources that rank above them. Large-animal resources contain energy-rich and nutrient-dense packages of macronutrients (protein and fat) and micronutrients (heme iron, zinc, vitamin $\mathrm{A}$, and some $\mathrm{B}$ vitamins) that are rare in most plant-based diets (Murphy and Allen 2003). Energy yields from animal resources can be high, especially if they contain fat (Speth 2010). However, processing costs can also be high without biological adaptations or technological interventions (Zink and Lieberman 2016). Inside-bone nutrients such as brains and marrow are the fattiest body parts on lean wild game, and the precursor to docosahexaenoic fatty acids (Langdon 2006) and oleic acids (Morin 2007) that play an important role in eye and brain development.

A group of medium-bodied hominins may have been capable of dispatching an animal the same size or larger than themselves. However, because cooperative hunting of large 
animals invokes a suite of assumptions about early hominin social structure that are difficult to test, we focus on the costs and returns associated with the most basic mode of acquisition: scavenging in a Pliocene context. These include potentially high search and handling costs, the chance of bacterial infection from rotten meat, conspecific competition, and exposure to large-bodied carnivores. Reduction of one or more of these costs could explain expansion of the diet to include a novel resource.

\section{Changing Costs and Returns of Large-Animal Resources}

Risk of exposure to predators likely increased as hominins began to exploit large animals in more open environments. Tappen (2001) found that exposure risk during passive scavenging differed substantially between environments; thus, the decision to scavenge is best modeled along a continuum of risk. New risk mitigation strategies would have already been necessary as hominins became increasingly terrestrial after $4.2 \mathrm{Ma}$ with group size likely mediated by this risk (Markham et al. 2015). In hominins, medium-sized multimale groups are implied from the fossil record where multiple individuals have been found together (Johanson 2004), even though body mass estimates show a high degree of body size dimorphism in Australopithecus (Grabowski et al. 2015).

Large group sizes may mitigate risk of predation by carnivores but also increase competition at scavenging sites. Scavenging also carries health risks. Outside-bone nutrients acquire harmful quantities of bacteria within 24 hours of exposure (Smith et al. 2015), receiving bacteria from carnivore mouths, insects, soil, scavenging birds, and fecal matter (Ragir, Rosenberg, and Tierno 2000). Chimpanzees avoid carrion, apparently deterred by risk of infection (Watts 2008). Gut microbiome composition - an unknown in early hominins - is dependent on diet and can alter an organism's ability to cope with foodborne illness (Josephs-Spaulding, Beeler, and Singh 2016). Where flesh was encountered in an early stage of carcass access, a mixed strategy of outside-bone and within-bone nutrients might have been facilitated by this. However, unbreached bone marrow retains low bacteria counts for much longer than exposed flesh or exposed bone marrow (Smith et al. 2015). This undoubtedly extended the amount of time it persisted in a fresh state, thus increasing encounter rates relative to edible flesh and decreasing risk from carnivores that remain near fresher kills.

In comparison to the outside-bone nutrients usually considered as the primary motivator for scavenging, inside-bone nutrients from scavenged carcasses are more likely to be highly ranked because of their persistence, palatability, and high fat content. Most small-bodied carcasses are divested of meat and marrow within a day, but marrow and brains can persist for several days in medium to large carcasses. Four major factors influence carcass persistence and nutritional quality: (1) carnivore guild composition, (2) habitat type, (3) season, and (4) prey body size (Blumenschine et al. 1987). Using models derived from observations of modern "Serengeti-like" ecosystems (both dry and seasonal), scavenging opportunities are most abundant during the dry season. When carcass availability is low, these kills are quickly stripped of meat (e.g., outside-bone nutrients) in a predictable sequence (Blumenschine 1986).

In modern Serengeti-like ecosystems, leopard kills have been found to provide some of the most persistent and predictable flesh-scavenging opportunities and are more readily encountered in riparian woodlands (Cavallo and Blumenschine 1989). Such environments are also inhabited by crocodiles, which may have presented unique scavenging opportunities in the form of thrown-off limbs (Davidson and Solomon 1990). However, in wetter and more closed environments, such as at Parc National des Virunga, (adjacent to the central African rain forest), wooded areas provide less frequent and higher-risk scavenging opportunities than more open areas (Tappen 2001). There, Tappen showed that passive scavenging of carcasses encountered during other activities was more productive than active searching, with most scavengable remains being inside-bone nutrients from medium-sized carcasses that each provided a median of ca. 2,000 kcal. Pobiner (2015) further demonstrates the ecological contingency of scavenging opportunities, especially relative to carnivore guild composition.

Although scavenging niches have been given much attention for Pleistocene hominins (Blumenschine 1989; DomínguezRodrigo 2001), less work has explored the implications of carnivore paleo-guild composition prior to ca. 2.6 Ma. The period before $\sim 3.9 \mathrm{Ma}$ is especially poorly sampled, but patterns in species richness in the east African carnivore guild show a peak at around 3.6 Ma, with the first appearance of several new species (Turner 1999). Starting ca. 2.0-1.5 Ma, there is a decline in carnivore richness to the present, with specialists going extinct in favor of more generalist taxa (Werdelin and Lewis 2005). The late Pliocene included species that do not have modern ecological analogues, including giant hyenids (Werdelin 1999), sabertooth felids (Marean and Ehrhardt 1995), and extinct crocodiles (Brochu and Storrs 2012).

This diversity of Pliocene carnivores points to more frequent and varied scavenging opportunities, as well as greater danger from predators at fresh kills, than are seen in modern African ecosystems (Blumenschine et al. 1987; Lewis 1997). Specifically, sabertooth felids were flesh specialists, and most had adaptations to closed-environment ambush hunting of large-bodied animals that are also now extinct (Parkinson, Plummer, and Hartstone-Rose 2015). Bone-cracking morphology evolved as a specialized adaptation for accessing inside-bone nutrients from large-bodied carcasses. In Pliocene Africa, this morphology first appears ca. 3.6 Ma (Turner 1999), suggesting the expansion of scavenging opportunities focused on insidebone nutrients that remained after flesh was removed. Australopiths were one of many groups jostling for emerging niche space at this time as resources changed in their distributions and open environments became more commonly exploited (Alemseged 2015). Through use of basic technology, Pliocene homi- 
nins could have rapidly taken advantage of the resources bonecracking carnivores were evolving to exploit.

\section{A Percussive Adaptation to Large-Animal Exploitation}

Although living apes are not direct analogues for early hominins, primate archaeology can provide predictions about the foraging circumstances under which the intersection of meateating and tool use should occur. Because stone is a raw material with a high likelihood of preservation, here we focus on use of stone tools. Where stone is available, tool use in primates often includes a percussive element, which appears to have evolved convergently multiple times across primate lineages (Haslam et al. 2009). Chimpanzees, capuchin monkeys (Sapajus spp.), and long-tailed macaques (Macaca fascicularis aurea) carefully select unmodified stones to smash open nuts or other tough food packages (Carvalho et al. 2008; Gumert and Malaivijitnond 2009; Visalberghi, Addessi, et al. 2009). This demonstrates that the cognitive foundations and anatomical requirements for repeated, socially influenced percussive technology is deeply rooted in the primate lineage, mainly within the context of accessing tough, high-value packages of proteins and lipids. Often, such extractive foraging is also associated with larger brain sizes (DeCasien, Williams, and Higham 2017).

Use of percussion in extractive foraging has been seen as a bridge to lithic reduction (Whiten 2015), and lithic production again as a necessary requisite for meat-eating (Zink and Lieberman 2016). However, the focus on outside-bone nutrients deflects from the potential for hominins to begin exploiting large-bodied animals in the absence of flaked stone. Flaked stone production is a case of secondary tool production; it requires at least one or two tools (a hammerstone and a nodule or an anvil and a nodule) to create another tool (a flaked stone). The scenario in which flaked stones must predate large-animal exploitation is unnecessarily complex, demanding creation of a new technology (flaked stone) to be applied to an equally novel purpose (cutting meat). Fewer steps are invoked if hominins first began exploiting large-animal resources through hammerstone percussion, which transfers an existing extractive technology from one similarly packaged resource (nuts or other encased foods) to another (bones). Chimpanzee use of stick tools follow this pattern, with tools originally used for one task repurposed to another (Wilfried and Yamagiwa 2014).

The appeal of bone marrow is common to both humans and our closest relatives. Bone marrow is dense in both calories and nutrients but poses similar problems to other encased foods: seasonal fluctuation (because marrow quality and fat content declines significantly when an animal is stressed; Blumenschine and Madrigal 1993), patchy distribution, and a hard outer shell. Among chimpanzees, unpredictability in space adds value to some resources upon encounter (Carvalho et al. 2012). The marrow of colobus monkeys and other prey is regularly eaten by wild chimpanzees by chewing off the extremities of long bones and sucking on or extracting the marrow with a probe (Boesch and Boesch 1990). In captivity, chimpanzees taught to smash open long bones will extract and eat it (Kitahara-Frisch, Norikoshi, and Hara 1987). Ungulate long bones filled with dried fruit are also opened by bonobos that recognize there is a treat inside (Roffman et al. 2015).

Increased encounter rates with scavengable inside-bone resources can explain how early hominins came to recognize this as a potential food. In chimpanzees, increased environmental variability has been shown to link with novel behaviors (Hockings et al. 2015). However, in modern, heavily forested environments, encounter rates with within-bone nutrients are low, and movable stones are not often readily available (Mercader, Panger, and Boesch 2002). Both apes and monkeys are heavily constrained in their tool use by the distribution and quality of suitable raw materials (Carvalho et al. 2008; Visalberghi, Spagnoletti, et al. 2009). Although it requires only simple technology, inside-bone resource scavenging does demand that tools be carried in case of encounter or that tool locations be remembered and carcass portions transported to those locations.

Chimpanzees conform their tool use behaviors as they move into new social or environmental settings (Luncz, Wittig, and Boesch 2015). They curate tools for later use (Mulcahy and Call 2006), and they return to the same tool composites (anvils and hammers) many times. They remember the locations of tools such as nut-cracking stones but will transport stone only up to a few hundred meters (Mercader et al. 2002). Over time, these stones could be transported several kilometers, providing the appearance of longer-term transport (Luncz et al. 2016)but always remaining in proximity to the resource. Scavengable carcasses are more widely distributed than nut-bearing trees. Percussive behaviors also have the potential to facilitate the production of "flakes," as unintentional by-products of anvil and hammerstone use (Carvalho et al. 2009). When bearded capuchin monkeys (Sapajus libidinosus) smash stones for nondietary purposes, they also ignore the resultant flakes (Proffitt et al. 2016). Early hominins would have been far less constrained in their ability to locate and carry stones, as they ranged in different kinds of environments and had anatomical adaptations for more energy-efficient load carrying (Carvalho et al. 2012).

\section{Paleoecology and Pliocene Hominin Diet}

Reconstructions of australopith paleoenvironmental settings show an increase in the use of open-habitat environments over the course of the Plio-Pleistocene (Behrensmeyer and Reed 2013). At this time, climate also became more intensely variable, creating larger regions of rapidly changing mosaic environments with multiple ecotones (Potts 2013). Current evidence also suggests that a shift in diet occurred in the hominin lineage by about 3.76 Ma (Lee-Thorp et al. 2010; Sponheimer et al. 2013). At this time, hominins began to more intensively exploit $\mathrm{C}_{4}$ resources in the relatively open environments that had been expanding across Africa since the Miocene. Australopithecus afarensis in Ethiopia and Kenyanthropus platyops in Kenya were the first hominins known to expand their dietary ranges away 
from that of extant apes and earlier hominins (Cerling et al. 2013; Wynn et al. 2013). By ca. 3.5 Ma, with later australopiths, brain size had undergone an increase proportional to the increase it would later see with Homo (Kimbel and Villmoare 2016), and canine size had already long been significantly reduced in both males and females. Hand proportions were also more humanlike than apelike, and adaptations for terrestriality were present throughout the skeleton (Ward, Kimbel, and Johanson 2011). Diversity in habitat preference characterized these and other later australopiths, with habitat reconstructions that range from relatively wet, closed woodlands to much more open conditions (Rowan and Reed 2015).

Carbon isotopic evidence from Au. afarensis (Wynn et al. 2013) and $A u$. africanus (van der Merwe et al. 2003) indicates increased use of open habitats but a diet highly variable between individuals. At least some individuals had diets largely based on foods that use the $\mathrm{C}_{4}$ photosynthetic pathway (tropical grasses and sedges) or herbivores/insects that fed upon those foods. In contrast, earlier hominins such as Au. anamensis or the even earlier Ardipithecus ramidus (White et al. 2009) included relatively few $\mathrm{C}_{4} / \mathrm{CAM}$ foods in their diet, showing stronger $\mathrm{C}_{3}$ signals more consistent with feeding off parts of shrubs and trees (Cerling et al. 2013). This provides further support for later australopiths as versatile omnivores that could exploit a range of resources across many habitats (Alemseged 2015).

\section{Taphonomic and Archaeological Evidence for Emergence of the HPP}

As reviewed earlier, activities falling under the rubric of "butchery" compose two main - and fundamentally different-activities: cutting and percussion. Cutting behaviors focus on processing of outside-bone nutrients such as meat, which are low in fat, putrefy quickly, involve higher risk of carnivore presence, and have low overall encounter rates because they occur on more complete carcasses. Percussion exploits inside-bone nutrients that are high in fat, persistent, transportable, low in bacteria loads, and less risky to exploit and that potentially have higher encounter rates. These two activities also leave taphonomic signatures that, although variable, are collectively different from one another in archaeologically detectable ways: the marks they leave on bones, skeletal element representation, and the degree and nature of skeletal part fragmentation.

Cut marks are traces left on bone surfaces by a sharp-edged object. They can be created by a variety of raw materials but are most often considered the by-product of flaked stone tool use. Flaked stone preserves well and provides contextual evidence that a locality was used by hominins, as well as a plausible explanation for how associated bones with linear marks became modified (Domínguez-Rodrigo et al. 2005; Njau 2012). Because flaked stone is robust and readily recognizable, there has arguably been undue bias on flaked stone tools and cut marks rather than percussive tools and percussion traces, which may be robust but not as easily recognized, as the primary forms of evidence for identifying butchered bone localities.
The problem is compounded because cut marks are prone to equifinality, where similar-appearing linear marks can also be caused by other agents such as trampling (Domínguez-Rodrigo et al. 2009). This must be considered as a potential problem at any site, even if there are associated stone tools. Another problem is that many different butchery processes can create cut marks that have a wide range of forms (Domínguez-Rodrigo and Yravedra 2009). Mark distribution and form can relate to the kind of butchery (e.g., filleting, disarticulation, chopping, slicing) but does not seem to relate to how much flesh was being removed (Merritt 2015). Moreover, chopping at carcasses with a flaked stone or a stone with a naturally sharp edge would leave a cutting trace even if the intent and action are percussive. For this reason, cut marks can overlap in morphology and size with marks more indicative of percussion (Blumenschine, Marean, and Capaldo 1996). Amorphous marks created by hammerstone percussion have not to date been subject to the same critique about equifinality as have cut marks, but they have also not been given the same scrutiny.

Marrow scavenging has been most intensively examined at Early Pleistocene sites, usually where flaked stone tools were widely employed and cut marks on fossils are common (Blumenschine et al. 2012). Percussion that is not related to stone knapping has also been reported from these contexts, occurring sometimes in volumes of stone material that far exceed volumes reported for flaked stone artifacts (Mora and de la Torre 2005). However, even at Oldowan sites with abundant pounding artifacts, both lithic and faunal analyses do not suggest that marrow extraction was the main activity taking placethe percussive tools were being extensively used for other processing (Diez-Martín et al. 2009). However, work has only recently begun on how to identify and/or analyze prospective pounding tools from earlier deposits (Benito-Calvo et al. 2015; Caruana et al. 2014).

Currently, the earliest reported butchery marks are from two ca. 3.4 Ma specimens recovered from the DIK-55 site at Dikika, in Ethiopia (McPherron et al. 2010). These marks have been alternatively interpreted as resembling linear trampling marks (Domínguez-Rodrigo, Pickering, and Bunn 2012) or crocodile tooth marks (Sahle, El Zaatari, and White 2017). However, the DIK-55 marks are outliers in terms of both size and shape when compared to a large sample of other marks on fossils from the same deposits and to experimentally produced trample marks (Thompson et al. 2015). This ambiguity in effector may at least partially be because many of the DIK-55 marks are quite deep and large, and in appearance they "transition from cutmarks to percussion marks in morphology" (McPherron et al. 2010:22 in supplementary information).

Although the DIK-55 specimens may represent early percussive butchery behavior, the next documented evidence derives from nine specimens (two of which conjoin) with only cut damage reported from the 2.6 Ma site of Gona, Ethiopia (Domínguez-Rodrigo et al. 2005). These are followed closely in time by three specimens, reported with both cut and percussion damage, from the $2.5 \mathrm{Ma}$ locality of Bouri in the Middle 
Awash deposits of Ethiopia (de Heinzelin et al. 1999). Cutmarked fossil bovid elements have also been reported from controversial 2.6 Ma deposits in the Masol region of the Siwalik Range of India (Malassé et al. 2016). However, all these cases represent very small samples that are widely separated in both time and space; systematic evidence of butchery does not become apparent in the archaeological record anywhere in the world until after about 2.0 Ma, at localities such as Kanjera South in East Africa (Ferraro et al. 2013).

The timing of appearance and pattern of abundance of the flaked stone record provides only circumstantial evidence that it emerged in tandem with the HPP, based mainly on the fact that it follows a similar chronological and geographic pattern. Stone tools have been reported from the Lomekwi 3 (LOM-3) site in Kenya, dating to ca. 3.3 Ma (Harmand et al. 2015). These tools were flaked and heavily used as anvils, appearing to have been produced through percussive techniques distinct from the production of later Oldowan tools - perhaps produced through a process similar to chimpanzee nut-cracking. Their function is unknown, but they could have been useful for both cutting and percussive activities. As with the DIK-55 fossils, this early date for flaked stone tool technology has been questioned (Domínguez-Rodrigo and Alcalá 2016).

By 2.6 Ma, again at Gona, hominins had begun to make Oldowan tools (Rogers and Semaw 2009). These and other early Oldowan assemblages show complexity in understanding of fracture mechanics and preferred transport of specific raw materials (Delagnes and Roche 2005; Stout et al. 2010), implying that their predecessors had accumulated experience with stone artifact manufacture that predated the Oldowan (Panger et al. 2002). Simple flaked stone artifacts are also reported to date to ca. 2.6 Ma at the Masol locality in India (Gaillard et al. 2016). However, like evidence for the HPP, flaked stone tools remain uncommon until ca. 2.0 Ma (Braun et al. 2010). In Africa after this time, they become a frequent component of the archaeological landscape (Plummer et al. 2009), where they were carefully selected and carried up to several kilometers from their sources (Braun, Harris, and Maina 2009). This inconsistent record may best be interpreted as the product of occasional, rather than obligatory, stone tool use that convergently emerged several times in many different places (Shea 2017a).

Until the recent work reviewed here, the earliest examples of the HPP and stone tool making were both known from the 2.6 Ma sites at Gona (Domínguez-Rodrigo et al. 2005). The prevailing view was that this time coincided with major speciation events in the hominin lineage (Ambrose 2001), a position reinforced by an example of early Homo from the nearby $2.3 \mathrm{Ma}$ deposits at Hadar, Ethiopia (Kimbel 2009). Now that the earliest Homo is reported at $2.8 \mathrm{Ma}$ from Ledi-Geraru, Ethiopia (Villmoare et al. 2015), the earliest evidence of butchery at 3.4 Ma from DIK-55, and the earliest flaked stone tools at 3.3 Ma from LOM-3, there has been a breakdown in this convenient and long-lived triumvirate: early Homo, the HPP, and the first flaked stone tools do not all appear to have emerged simultaneously at the start of the Pleistocene. Now, the candi- date hominins for the origins of both behaviors appear to have been australopiths living at least 700,000 years earlier.

\section{Percussion Scavenging}

In light of the theoretical and empirical evidence just reviewed, we argue that the transition to the HPP was not reliant on concurrent flaked stone tool technology to cut meat but rather that percussive extraction of inside-bone nutrients offers a more parsimonious pathway by which hominins first made regular use of large-animal resources (fig. 1). This is anticipated to leave a different archaeological and taphonomic signature than outsidebone nutrient extraction, thus rendering traditional emphasis on "cut marks" caused by meat processing less informative for understanding how large-animal exploitation first emerged. Under the percussion scavenging model of the origins of the HPP, both percussive extraction and flaked stone tool manufacture represent fundamentally different behaviors applied to substrates with different spatial distributions, characteristics, costs, benefits, and processing requirements. They need not have been behaviorally linked nor have emerged together.

Paleoanthropologists must resist being constrained by the known archaeological record. For example, percussion scavenging does not require the use of any stone tools. Perishable materials such as tree boles and friable lateritic soil have been used by chimpanzees to crack nuts, especially in areas poor in stone (Marchant and McGrew 2005; Mercader et al. 2002). Experimental work may also reveal that bone hammers are effective for breaking other bones, as later in time they became important percussors for working stone (Rosell et al. 2011). Within this theoretical framework, we make several predictions about the conditions under which the HPP emerged and what evidence should be associated with it.

\section{Spatial Distribution and Frequency}

Because of the patchy and unpredictable distribution of scavengable inside-bone resources, their exploitation should have been generally opportunistic, seasonal, and contingent on local ecology. Thus, evidence for the behavior should be overall rare but with concentrations near rivers, streams, and potentially within areas that were within the home range of a resident carnivore- especially felids. We predict the behavior to become more common and widely distributed when hominins began to more regularly challenge large scavengers and predators for fully fleshed carcasses. Although this prediction is not reliant on knowing the degree of risk involved in scavenging within extinct Pliocene ecosystems, scavenging risk could be quantitatively modeled to provide more precise predictions for when and where such a transition took place.

\section{Direct Evidence}

Percussion scavenging should be evidenced primarily by percussion marks and notches on highly fragmented long bone 


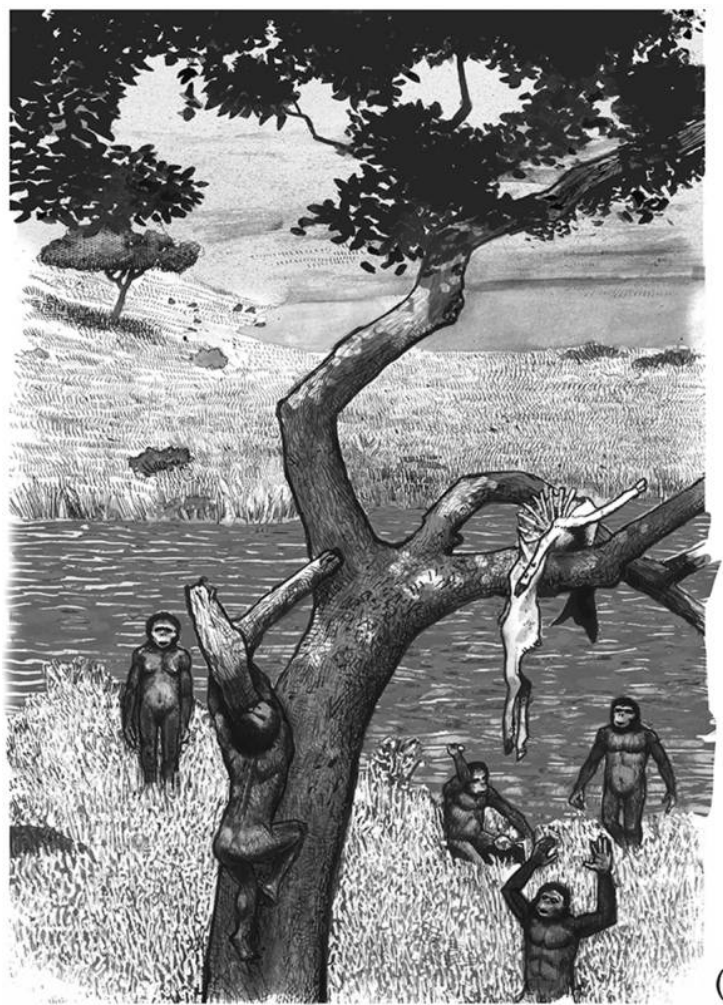

(a)

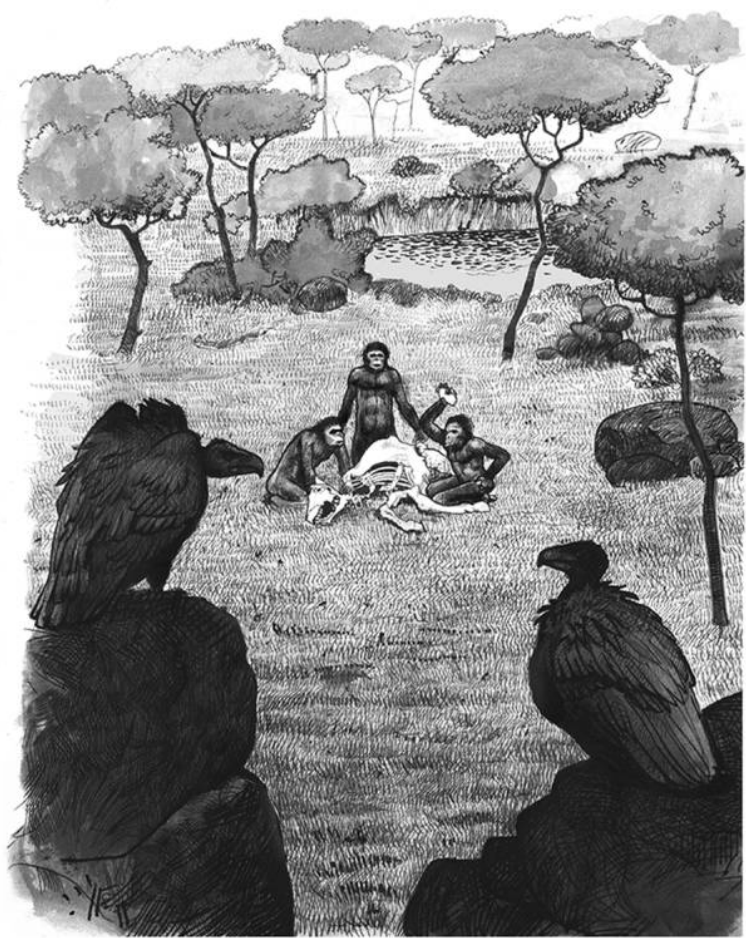

(b)

Figure 1. $a$, The former meat-eating scenario, in which hominins create accumulations of flaked stone tools at focal points on the landscape, in association with the partially fleshed animal carcasses they are consuming. This places emphasis on consumption of outside-bone nutrients, production of cut marks, and the formation of "sites" containing flaked stone. $b$, The percussion scavenging scenario, in which hominins focus on percussion-based extraction of inside-bone nutrients from carcass portions that persist on the landscape. This does not result in large accumulations of flaked stone and bone, and most damage signatures are percussion marks and bone fragmentation.

shafts, mandibles (which also contain a marrow cavity), and cranial fragments. These should be found in localities that offered opportunities for scavenging and raw materials for percussive implements, along with a high likelihood of rapid burial and therefore good bone surface preservation (Thompson et al. 2015). Alternatively, accumulations of marked bones may occur together where they were transported to safer localities. Such sites may or may not also have discarded hammerstone or anvil elements with macroscopic and microscopic evidence of battering and other use wear (Benito-Calvo et al. 2015).

\section{Associated Evidence}

If percussion tools were transported, then evidence for percussion scavenging is likely to also be found at "Type M" sites, where modified bones are found without association with flaked stone artifacts (Bunn 1994). Marked bone surfaces need not be restricted to sites with nonperishable or recognizable percussors but should usually occur on or in close spatial proximity to other indicators of percussion activity, such as bone flakes and notched long bone shafts (Marean and Bertino 1994).

\section{Discussion}

Disparate lines of evidence have begun to increasingly coalesce on a picture of the late Pliocene as a period marked by opportunistic and eclectic foraging by hominins that were manually dexterous and behaviorally flexible and that regularly exploited a varied diet from a range of both open and closed habitats. Early hominins such as Australopithecus had relatively large brains, humanlike hand proportions, small canines, and a high degree of terrestriality. These features strongly suggest that extractive foraging and tool use were already present and that these factors were the substrate upon which the HPP was built. At some point in evolutionary time, the benefits of large-animal exploitation began to outweigh the costs. We propose that this was achieved in the late Pliocene largely through the application of percussion to extract inside-bone nutrients. This has implications for the reconstruction of early hominin paleobiology and ecology, as well as an opportunity for a fresh look at the behavioral implications of the beginnings of the HPP.

Although research surrounding the HPP revolves almost exclusively around male strategies, this perspective suggests a stronger female role in at least the initial movement into a 
scavenging niche (Zihlman 2012). Among chimpanzees, females and juveniles are the subsets that most frequently use tools, and most social transmission about tool use skills takes place between mother-offspring dyads (Lonsdorf 2006). Active hunting is normally a male activity (Fahy et al. 2013; Stanford 1995), which shares a tempting parallel with modern huntergatherer social organization. However, female and juvenile chimpanzees hunt for small-bodied primates using tools to probe them from tree trunks (Pruetz and Bertolani 2007), and female bonobos also participate in hunts (Hohmann and Fruth 2008). Percussion scavenging, especially in large social groups, would have opened similar opportunities to females and juveniles already engaged in tool-assisted extractive foraging. Unlike scenarios of human evolution in which females are passively provisioned with meat, early large-animal exploitation may have been at least initially driven by female strategies.

These and other higher-order interpretations are reliant on concordance with the empirical record. Reports of flaked stone artifacts and butchered bones from deposits dating between 3.3 and 3.4 Ma suggest that both behaviors likely arose earlier than what was previously known, at 2.6 Ma. Until more older localities are reported, it is premature to assign a specific function to the tools or to interpret the stone flaking and largeanimal butchery as either a widespread or a critical part of the early hominin adaptation. It is also difficult to interpret where they fit in the overall sequence of behavioral change. Even tools such as at LOM-3 may represent a relatively late manifestation of stone tool use that began long after percussive extractive foraging behaviors such as those used by chimps were already in place. At present, the LOM-3 and DIK-55 cases are both singular and demand much further work (Domínguez-Rodrigo and Alcalá 2016).

However, such discoveries have pushed paleoanthropology into fresh directions for understanding the origins of the HPP. Most important, they illustrate the need for a shift in our theoretical framework and systematic survey for evidence of Pliocene butchery through a range of proxies (stone percussors as well as flakes, and percussed as well as cut bone). Rather than disassembling familiar paradigms about the significance of these behaviors in human evolution (Aiello and Antón 2012; Domínguez-Rodrigo et al. 2014), these new data point to two thresholds of inquiry: (1) when and why the behaviors first began and (2) when and why they later became more complex and systematic.

The realities of the archaeological record are that it preserves stones well, and bones far better than traces of other potentially important aspects of diet, such as starchy plants (Hardy et al. 2015). Modified bone surfaces provide direct evidence that stone tools were at least sometimes employed in butchery activities, but preservation and research bias have arguably both contributed to the impression that flaked stone tools and the HPP are dependent upon each other. By conceptually stepping away from the traditional pairing of meateating and flaked stone tool manufacture, we critically examine the process by which large-animal tissues first became incorporated into the hominin diet, how important they were prior to the emergence of Oldowan technology, and how this behavior should have been manifested in recognizable ways on Pliocene paleolandscapes.

The likelihood of discovering relevant sites has arguably been impacted by a lack of systematic survey in Pliocene deposits, as well as a search image aligned mainly to flaked stone. However, evidence may also simply be very rare because of one or more other possibilities (Panger et al. 2002): (1) these behaviors were deployed by early hominins inconsistently and played a marginal role in day-to-day foraging, (2) activities may have been done while "foraging on the go" and not concentrated at central places that form the "sites" composing most archaeological investigation, (3) tools unmodified prior to use are difficult to identify, (4) diagnostic characteristics of pounding tools may weather readily over long periods, and (5) group sizes of tool-using hominins may have been smaller and thus left smaller quantities of concentrated debris.

Only fieldwork explicitly designed to test these scenarios can provide an answer. In light of the literature reviewed here, we provide the following empirical expectations:

1. Evidence for the earliest consumption of animal tissues should be rare.

2. Evidence for the earliest consumption of animal tissues should be primarily from percussive activities aimed at insidebone tissue.

3. Evidence for percussion scavenging should primarily be in the form of modified fossil surfaces with notches, associated bone flakes, and fragmented long bones.

4. Bone surface modifications should exhibit a wider range of sizes and morphologies than has been reported in the existing taphonomic literature, and marks should be deeper and more often amorphous than linear.

5. Fossil evidence should be spatially associated with prospective percussors, or with microhabitats that offered perishable percussors (e.g., large trees).

6. Percussors should exhibit a well-defined damage type, which may be subtle.

7. Evidence for percussion scavenging should be preferentially found where opportunities for transport of scavenged resources and bone surface preservation intersected, for example, lake margins and riparian woodlands where hominins cached stone or used trees as refuge.

We advocate a new methodology of field research to test these predictions that is essentially an archaeological approach to deposits previously thought to be purely paleontological. We also provide recommendations for development of an interpretive framework for these methods (table 1). We have begun to implement some of these approaches through fieldwork, museum research, and methods development - starting with a taphonomic study of sieved fossil collections from Dikika (Thompson et al. 2015), systematic survey and collection of modified bones at Hadar, Ethiopia (Thompson et al. 2016), and deployment of novel methods for the identification and 
Table 1. Summary of key gaps in data to be addressed with new field approaches and explicit development of interpretive frameworks

\begin{tabular}{ll}
\hline Problem & \multicolumn{1}{c}{ Solution } \\
\hline $\begin{array}{c}\text { Field method: } \\
\text { Bias toward flaked stone tool localities }\end{array}$ & Systematic survey for percussors and flake stones in Pliocene deposits \\
& Training of workers and students to recognize potential percussive tools \\
& Experimental replication of potential stone percussors \\
Lack of microscale data about taphonomic & Sieved samples of fossils that map microhabitat occurrences likely to preserve bone \\
alterations & Systematic documentation of scavenging opportunities via paired sedimentary and \\
& taphonomic variables \\
Understanding the distribution of bones broken & Systematic collection and refitting of fragmented long bones \\
by different taphonomic agents & Systematic documentation of bone surface modification \\
Lack of diversity in referential models of & An expanded experimental taphonomy program that emphasizes the material traces \\
percussion traces & of percussive scenarios \\
& Different raw materials (different types of rocks, bone, wood, hardened sediment) \\
& Different technology types (rounded stones, sharp stones, Lomekwian tools) and animal \\
& body sizes (medium and large) \\
Interpretive framework: & Increase paleoecological research on Pliocene carnivore guild structure and scavenging \\
Poor resolution about scavenging opportunities & niches \\
& Refine neotaphonomic models to emphasize how predator-prey events at the moment of \\
& carcass acquisition influence nutrient availability \\
& Additional work on the relationships between microbiome and dietary constraints/choices \\
Need for specificity in foraging constraints & Develop nutritional data and foraging models that quantify the costs, returns, and spatial \\
& distribution of marrow exploitation opportunities relative to other resources \\
Lack of data on energetics and biological & Examine percussive biomechanics and energetics in apes, humans, and extinct hominins \\
constraints on percussion &
\end{tabular}

analysis of bone marks (Harris et al. 2017; Otárola-Castillo et al. 2018).

\section{Conclusion}

A simple argument from the temporal coincidence of the earliest known flaked stone tools and evidence for large-animal resource exploitation lacks explanatory power about the emergence, role, and relationship of these behaviors in early hominin ecology and evolution. Although some elements of anatomical and behavioral changes appear in our lineage by ca. 2.8-2.4 Ma, these do not become consistently expressed for at least another 400,000 years - or potentially longer. The paradigm under which the emergence of Oldowan stone tool manufacture coincides with consistent, repeated large-animal butchery by members of the genus Homo (among potentially, other species) still appears useful and coherent. However, current evidence does not support the interrelationship of these three events (advent of flaked stone tools, large-animal exploitation, and speciation into Homo) as an explanation for their origins. Instead, new theoretical and empirical approaches must be developed to understand the context of their earliest, and potentially decoupled, emergence. Here, we propose a new model: the regular exploitation of large-animal resources - the HPP — began with an emphasis on percussion-based scavenging of inside-bone nutrients, independently of the emergence of flaked stone tool use.

\section{Acknowledgments}

The ideas presented here were generated through discussions with Bill Kimbel, Andrew Barr, Denné Reed, Shannon McPherron, and René Bobe. Bill Kimbel provided valuable comments on an earlier draft. J.C.T. and C.W.M. recognize the support of the John Templeton Foundation (to the Institute of Human Origins). The opinions expressed here are those of the author(s) and do not necessarily reflect the views of the John Templeton Foundation. We are very grateful to Luis da Silva for providing the illustrated alternative scenarios. Three anonymous reviewers and the editorial team at Current Anthropology provided much constructive critique and greatly improved the article. This article was conceptualized while the lead author was based at the University of Queensland and written while at Emory University.

\section{Comments}

\section{David R. Braun}

Center for the Advanced Study of Human Paleobiology, George Washington University, 2110 G Street NW, Washington, DC 20052, USA (drbraun76@gmail.com).

\section{Pliocene Hominin Behavior: New Insights}

Pliocene hominin behavior has gone from the relatively unknown to one of the most exciting new components of our 
understanding of the archaeological record. This is in part because of new data detailing both the appearance of stone artifacts (Harmand et al. 2015) and evidence of cut marks on bone surfaces (McPherron et al. 2010). Regardless of your stance on the earliest evidence of these behaviors (DomínguezRodrigo, Pickering, and Bunn 2011; McPherron et al. 2011; Sahle et al. 2017; Toth 2017), most paleoanthropologists recognize that our current data set for this time frame $(>2.6 \mathrm{Ma})$ requires substantially more data before we can make definitive claims about hominin behavior. However, these discoveries combined new insights from the study of nonhuman primate tool use suggest that our current paradigms likely need to shift (Biro, Carvalho, and Matsuzawa 2010; Carvalho et al. 2008; Haslam et al. 2009, 2013). I applaud Thompson and colleagues for incorporating this new data to create a new perspective on hominin carnivory in the Pliocene.

I agree with their assertion that the zooarchaeological record as well as our knowledge of Pliocene hominin diet (Sponheimer et al. 2013) does not seem to record major changes at the time when Oldowan stone artifacts are first recovered from the archaeological record (Domínguez-Rodrigo 2009; Robinson et al. 2017). Although there are good reasons to believe that the zooarchaeological record does not always faithfully reflect the patterns of resource acquisition (Domínguez-Rodrigo and Yravedra 2009), the large assemblages with clear evidence of human activity that appear after $2 \mathrm{Ma}$ (Ferraro et al. 2013) are conspicuously absent prior to $2 \mathrm{Ma}$. Why do we not see localities that have single carcasses associated with large numbers of artifacts, such as Site 15 at Olorgesailie (Potts 1989), in time frames between 2.55 and 2.0 Ma? A possible answer is that stone artifacts were not necessarily a frequent part of the hominin tool kit prior $2 \mathrm{Ma}$ (Shea 2017a). If that is the case, then maybe our inferences about the nature of hominin carnivory should also be shifted.

A major insight by Thompson and colleagues is the ability to view the archaeological record from the perspective of new data on the behavioral record of other primates (Carvalho et al. 2008). Thompson and colleagues are careful to use this record to develop inferences while recognizing the potential pitfalls of this kind of comparison. One of the implications of the human predatory pattern, as they describe it, is for percussive tools to play a much bigger role in the Pliocene archaeological record. Many primates use percussive tools, and as such it makes sense that these would be major component of the earliest technology (Haslam et al. 2013; Luncz, Mundry, and Boesch 2012). The frequency of these tool forms in the Lomekwi record would seem to support this assertion (Harmand et al. 2015). However, the relative lack of these tools in even the next youngest archaeological assemblages (e.g., Gona; Stout et al. 2010) suggests a possible disjoint between Pliocene and Pleistocene technologies. Further, if we use the tool use of primates as a phylogenetic analogy, then it is possible that the percussive tools we see in the modern primates represent a relatively young phenomenon (Haslam 2014). Furthermore, despite extensive experimental studies (Benito-Calvo et al. 2018; Caruana et al. 2014; de la Torre et al.
2012; Mora and de la Torre 2005), the recognition of percussive tools remains somewhat elusive. Considering the difficulties faced with identifying bone surface modifications (Harris et al. 2017; James and Thompson 2015; Thompson et al. 2011), the identification of percussive tools will pose new challenges.

A further complication in the identification of percussive technology relates to the use-lives of these tools. Percussive tools frequently have relatively longer use-lives compared to chipped stone artefacts (Carvalho et al. 2008; Shott and Sillitoe 2005). The implication for Pliocene assemblages is that we should not expect to find large concentrations of these tools. If the identification of percussive tools requires microscopic scanning of surfaces, then collection procedures will need to radically change at Pliocene sites. Making the argument that numerous isolated stones need to be collected from Pliocene localities will certainly draw ire from museums that already have difficulty storing the voluminous paleoanthropological record. Finally, the identification of percussive technology from the remains of bones that were broken open for within bone nutrients poses similar difficulties (Ferraro et al. 2018). If we are to test the HPP, dramatic new increases in our ability to identify subtle traces of behavior must be developed.

The premise of the HPP hypothesis is interesting, and the authors should be commended for the testable expectations of this hypothesis that they provide. One concern is the assertion that small animals would not have ranked highly in the diet of Pliocene hominins. Thompson et al. suggest that because chimpanzees often forego hunting of low-cost items (e.g., monitor lizards), and other prey items require specialized adaptations (e.g., levels of arboreality that allow for the hunting of smaller primates), small animals were an unlikely resource for Pliocene hominins. However, as they also note, these high-dietary-quality items rarely provide substantial caloric contributions (Tennie, O’Malley, and Gilby 2014). Indeed, hunting among chimpanzees appears to be more related to certain social and ecological conditions (Mitani and Watts 1999). Some small prey may have higher acquisition costs because they require specialized technology to capture them (Clark and Plug 2008). However, many smaller prey items can be captured with little to no technology (Archer et al. 2014; Stewart 1994). Some small aquatic resources have relatively high return rates and maintain high fat content in times of the year when large mammals are relatively depleted of fat (even within bone nutrients; Caruana et al. 2014; Hawkes, O'Connell, and Jones 2014; Madrigal and Blumenschine 2000; Stewart and Gifford-Gonzalez 1994). Although hominins may have increased return rates by focusing on within-bone nutrients in large animals, they also would have been moving into this niche at a time when bone-crunching carnivores were numerous (Lewis 1997; Werdelin and Lewis 2013;Werdelin, Lewis, and Haile-Selassie 2014). Small prey may have been a difficult prey item to capture, but evidence from both the ethnographic and archaeological record suggests that hunters with relatively basic technology can access this resource (Ferraro et al. 2013; Hawkes 1990; Hawkes et al. 2014). It is possible that small prey items were a part of the hominin dietary pattern for much of our 
lineage, yet the evidence of these resources may be difficult to identify (Behrensmeyer, Kidwell, and Gastaldo 2000).

Much of our understanding of hominin behavioral ecology rests on the substantial investigations on this topic beginning several decades ago (Blumenschine, Cavallo, and Capaldo 1994; Oliver 1994; Plummer and Bishop 1994; Rogers, Harris, and Feibel 1994). Since those landmark studies, our knowledge of hominin behavior (Harmand et al. 2015; McPherron et al. 2010) and biology (Sponheimer et al. 2013; Ungar, Grine, and Teaford 2006; Villmoare et al. 2015) has changed substantially. I agree with Thompson and colleagues that it is time to view this record with a different perspective. As always, the devil is in the details.

\section{Michael Pante}

Department of Anthropology, Colorado State University, 1787 Campus Delivery, Fort Collins, Colorado 80523, USA (michael .pante@colostate.edu). 10 II 18

Over the last few years, Thompson and colleagues have taken a systematic approach to improving the methods and standards that we employ in investigating the earliest archaeological record. Here they present a theoretical and semantic rebranding of human carnivory and its uniqueness when compared with the carnivorous components to the diets of our nonhuman primate relatives. Central to their argument is what they believe is an overemphasis on meat-eating and unjustified reliance on models derived from living ape ecology that postulate the consumption of large prey in our ancestors emerged from cooperative hunting of smaller prey, a behavior observed in our closest living relative, the chimpanzee. They suggest the earliest evidence of what they term the "human predatory pattern" (HPP) should be in the form of trace evidence of percussion activities, such as percussive technology and percussion damage inflicted on bones during the extraction of within-bone nutrients, which are rich in fat and remain edible for far longer than flesh after the death of an animal.

Others (Binford 1988; Blumenschine 1995; Capaldo 1997; Selvaggio 1998) have emphasized the importance of withinbone nutrients in early hominin subsistence strategies, suggesting our ancestors likely acquired large mammal carcasses that were mainly devoid of flesh through passive scavenging from the kills of carnivores. However, these hypotheses were based on the 1.8 Ma FLK 22 Zinjanthropus assemblage from Olduvai Gorge, Tanzania, and at the time, the potentially much deeper antiquity of the evidence for human consumption of large prey was not yet appreciated. Given the substantial temporal expansion of the archaeological record since the debate over the FLK Zinjanthropus assemblage began, the reframing of our hypotheses is long overdue. However, investigators of the emergence of the HPP must overcome considerable challenges, especially if this behavior began in the form of percussive activities, as Thompson et al suggest.
Our current appreciation for the signatures left by the extraction of within-bone nutrients and their potential to be mimicked by other biostratinomic and diagenetic processes is extremely limited. Actualistic research on trace evidence for within-bone nutrient extraction found on artifacts and bones lags far behind that for outer-bone nutrients, where there has been a recent explosion of innovative methods proposed to improve the reliability of cut mark identification (Harris et al. 2017; Otárola-Castillo et al. 2018; Pante et al. 2017). None of these techniques have been applied to percussion damage, and researchers are left to rely on qualitative criteria, first published decades ago (Blumenschine and Selvaggio 1988) to identify percussion marks on bones or distinguish hammerstone impact notches from those inflicted by carnivore teeth (Capaldo and Blumenschine 1994). Just as problematic as the identification of traces on bone are the use-wear traces on the tools used for exposing within-bone nutrients, which have recently been shown to be minimal and difficult to distinguish from those produced by stone tool manufacture (Benito-Calvo et al. 2018). Given the limitations of our knowledge, the paleoanthropologist is incredibly ill-equipped to find early evidence of the HPP, especially if it is in the form of percussion damage on bone or tools.

Even the more extensively studied trace evidence of outerbone nutrient extraction in the form of cut marks or flaked stone tools is difficult to reliably identify in the patchy Pliocene archaeological record. The 3.4 Ma marks from Dikika have been differentially interpreted as cut marks (McPherron et al. 2010), trample marks (Domínguez-Rodrigo et al. 2012), and crocodile tooth marks (Sahle et al. 2017), all using methods that are qualitative and impossible to evaluate for accuracy. Here, Thompson et al. suggest that the apparently anomalous depth of the marks on these specimens may indicate a percussive origin. However, the depth and morphology of the marks is not outside the range of those inflicted by the powerful jaws of crocodiles that use dynamic impacts, like those inflicted by hominins wielding hammerstones, to kill and dismember their prey (Njau and Gilbert 2016). The traces left by this distinct feeding behavior can produce not only V-shaped pseudocut marks but also pits with associated microstriations that are easily mistaken for percussion (Njau and Gilbert 2016). My own observations of crocodile-modified bones indicate that they can also create notches and flake scars that are similar to those inflicted during hammerstone percussion. Evidence of crocodiles at Plio-Pleistocene archaeological sites is common, but their potential to mimic the feeding traces of human ancestors has only begun to be recognized. As such, any identification of human predatory behavior in the Pliocene is premature and should not be accepted until we meet methodological standards of inquiry that are currently well beyond our capabilities.

If we are to identify the earliest evidence of the HPP in the archaeological record, we need to completely revolutionize and standardize our approach to this investigation. We need to work together to develop a greatly expanded and open-access 
actualistic database aimed at understanding the potential for equifinalities between traces left by human carnivory on bones and tools and those left by any bone or stone modifying process that we can replicate. We need to further invest in the new identification methods that are in development (Harris et al. 2017; Otárola-Castillo et al. 2018; Pante et al. 2017) and apply them to our actualistic samples, for it is in this application that we can potentially break equifinalities perceived through traditional qualitative methods of analysis. We need to implement blind testing to ensure that these methods are accurate and replicable between research teams, and we need to anticipate the effects of postdepositional processes on the criteria used by our models. These standards are difficult to meet, and it will take years if not decades to adequately satisfy the outlined expectations. However, we can no longer rely on the approaches that have led to a complete lack of consensus among researchers. Thompson and colleagues have already begun to undertake these challenges, and we have reason to be hopeful that paleoanthropologists will ultimately meet the higher proposed standards in our investigations of the HPP.

\section{John J. Shea}

Anthropology Department, Stony Brook University, Stony Brook, New York 11794-4364, USA (john.shea@stonybrook.edu). 10 I 18

I congratulate Thompson and colleagues on a substantive and thoughtful contribution to the Plio-Pleistocene hunting versus scavenging debate. Using the same term for different things is never a good idea. Meat-eating and stone tool use are just such "two-for-one" concepts. Their description of the HPP teases these concepts apart, contrasting the costs, benefits, and risks of using stone cutting tools to detach meat-protein from largeanimal carcasses with those involved in using percussive tools to extract marrow-fat from inside large-animal bones. The paper argues that percussive fat extraction preceded stone cutting tool use as the HPP's foundational strategy.

Thompson and colleagues make explicit predictions about what we should find if their hypothesis is correct, and they call for increased scrutiny of those Pliocene sedimentary deposits likely to contain relevant evidence. For this research to be successful, it has to be done mindfully. Paleoanthropological claims of the earliest anything invariably ignite controversy. Much controversy about early stone tool use focuses on the criteria for recognizing hominin agency in modifications to stone or bone. All too often, archaeologists develop these criteria after the fact of discovery, and the criteria in question include subjective, visually assessed morphological analogies and appeals to authority. This must change. Paleoanthropologists need to reach consensus about objective measurement-based criteria for recognizing percussion-damaged bone and stone before we invest much time and energy defending our preferred interpretation of one or another lithic or faunal assemblage. (Remember, evolution's opponents read our professional disagreements as epistemological uncertainty.)

Inasmuch as this paper offers predictions for the zooarchaeological evidence, the rest of my remarks focus on its implications for the lithic record. For humans and our hominin precursors, stone cutting tools are, in essence, artificial teeth and nails. Chimpanzees use their teeth and nails to kill and eat smaller animals, but they also use their teeth and nails to shape wooden artifacts. Humans use stone cutting tools as butchery aids, and we use them to shape wooden tools, things for which we do not generally use our teeth or fingernails. Because fossilized bones preserve better than wood, and because some PlioPleistocene bones have stone tool cut-marks on them, paleoanthropologists have long assumed that the first stone cutting tools were butchery aids. In fact, no prior theory justifies making this assumption. Hominins might have used stone cutting tools as aids to carpentry for eons before repurposing them as butchery tools. Which of these is the more primitive or derived hominin behavior remains unknown, but it is an issue on which only archaeology can shed light. Thus far, nearly every Pleistocene sedimentary deposit in which archaeologists have found preserved wood also preserves wooden artifacts with stone tool marks on them. Unless the Early Pleistocene archaeological record hides some as-yet-undiscovered "Carpentry Revolution," one expects that if we ever find Plio-Pleistocene-age wood, we will also find purposefully shaped and cut-marked wooden artifacts.

One agrees with Thompson and colleagues that "paleoanthropologists must resist being constrained by the known archaeological record," but neither should we limit our hypotheses about early hominin tool use to what apes and monkeys do with rocks and sticks. Archaeologists welcome insights from ethology and experiments with captive primates, but many such studies emphasize broadly defined behavioral similarities among "technological primates" rather than important differences (Shea 2017b). Focusing on similarities distracts us from evolutionary anthropology's most important question: how differences between humans and other primates evolved. In evolution, only differences matter.

Let us consider stone percussors. Thompson and colleagues write, "Even at Oldowan sites with abundant pounding artifacts, both lithic and faunal analyses do not suggest that marrow extraction was the main activity taking place- the percussive tools were being extensively used for other processing." These other percussive activities might have included nut cracking or other plant food-processing tasks similar to what some living nonhuman primates do with stone percussors, but they could include activities only living humans do together with quintessentially hominin qualities of behavioral variability. Percussion makes noise, and percussion instruments are either human universals or nearly so. Depending on terrain, vegetation, and atmospheric conditions, noise from stone-on-stone percussion carry for hundreds of meters or more. Humans are more prosocial than apes are. Perhaps our hominin ancestors used stone percussion to signal and locate 
one another in dense vegetation so that they could find and groom one another and unite for common defense as night fell and carnivores stirred to life. Stone-on-stone percussion produces sharp reports that can drive away carnivores. (If this does not work, thrown projectiles effectively clarify the "humans + noise = pain" equation.) Early hominins had larger brains than living apes do and, it follows, led more complex social lives (Dunbar 2016). Stone-on-stone percussion might have been part of social performances, precursors to such uniquely human institutions as music and song (Mithen 2005). Might the oldest stone percussors and flaked tools have been by-products of such noise making later coopted into use as aids to resource extraction and tool making? Perhaps they served all these purposes simultaneously, or differently in response to situational variables. Can we identify these different activities' lithic signatures? Not yet, but we will never know whether we can unless we start asking more expansive questions about early stone tools. Primitive means "ancestral." Just because Plio-Pleistocene hominins made stone tools long ago does not mean their strategies for using those tools were simple. (After all, those ancestral hominins "invented inventing.") The more we study nonhuman primate tool use, the more complex it appears. We should anticipate the same learning curve in research on early hominin technology.

\section{Elisabetta Visalberghi}

Istituto di Scienze e Tecnologie della Cognizione, National Research Council of Italy (CNR), via Aldrovandi 16 b, 00197 Rome, Italy (elisabetta.visalberghi@gmail.com). 27 II 18

\section{Meat Exploitation: Reflections \\ by a Cognitive Primatologist}

The article "Origins of the Human Predatory Pattern: The Transition to Large-Animal Exploitation by Early Hominins" brings an innovative approach to investigate the predatory pattern(s) of the hominin lineage. A critical examination of the state of the art has led Thompson et al. to argue that "the transition to the HPP was not reliant on concurrent flaked stone tool technology to cut meat, but rather that percussive extraction of inside-bone nutrients offers a more parsimonious pathway by which hominin first made regular use of largeanimal resources."

This new focus opens a refreshing window to look at the costs and benefits of extracting inside-bone nutrients (e.g., bone marrow and brain) versus outside-bone nutrients (e.g., meat). As a cognitive primatologist, I consider that the proximate mechanisms of extant nonhuman primate behavior are inspirational to draw possible scenarios of meat consumption by early hominins. Specifically, I argue that capturing small prey allows the individual easy access (i.e., without the use of tools) to brain and marrow and that the consumption of meat and softer body parts (brain, marrow, viscera) allows the individual to learn to prefer the latter by means of their better payoff. In turn, this preference may motivate the individual to access encased brain and marrow of large preys by using pounding tools to exploit inside-bone nutrients. Let us now consider the evidence supporting this view.

Chimpanzees and bonobos "hunt, but never for prey larger than themselves" (Thompson et al.). The same holds true for capuchin monkeys (genus Cebus and Sapajus; even though I observed four young bearded capuchin monkeys together hunting an iguana twice as big as each of them - the iguana was not killed, but its tail was torn off and each monkey got its share; Visalberghi and Albani 2014). Chimpanzees and capuchins eat the different body parts of the prey often starting from, or privileging, the viscera and the brain, that is, the softer parts (Prieto 2013; Tennie et al. 2014). The caloric contents of these food sources are not strikingly different, although microand macronutrients are. ${ }^{2}$

Animals learn what to feed upon from the feedback provided by each food (Galef 1996; Visalberghi et al. 2003). Experimental evidence demonstrates that in capuchins, food preferences are significantly related to the energy intake rate (kilojoule ingested per second), that is, to the amount of energy ingested per unit of time (Stammati, Sabbatini, and Visalberghi 2008). However, food preferences are not significantly related to ingestion rates (grams of food ingested per unit of time) and to food energy content alone (kilojoule per gram). These findings may well account for a stronger preference for soft body parts (e.g., brain, viscera, and bone marrow) than for meat, the consumption of which requires longer mastication and provides less energy per unit of time.

The preceding findings on living nonhuman primates strengthen the argument that early hominins, well before flaking to cut meat, used pounding tools to access brain and bone marrow and, why not, to tenderize meat and reduce mastication time.

\section{Lars Werdelin}

Department of Palaeobiology, Swedish Museum of Natural History, Box 50007, SE-10405 Stockholm, Sweden (werdelin@nrm.se). 4 III 18

I am in complete agreement with the general principles and reasoning behind the paper by Thompson et al. on the HPP. Nevertheless, it does require some comment, and perhaps clarification of a sort, from the perspective of the carnivoran mammals (members of the Order Carnivora-distinct from

2. US Department of Agriculture, National Nutrients Database for Standard References, https://www.ars.usda.gov/northeast-area/beltsville-md -bhnrc/beltsville-human-nutrition-research-center/nutrient-data-laboratory /docs/usda-national-nutrient-database-for-standard-reference/. 
carnivores, animals that exploit animal dietary resources) that early hominins came into conflict with due to the development of the HPP.

Looking back into the Pliocene and Pleistocene, hominoids and carnivorans are unusual among nonobligate herbivores in that both groups include members reaching a large body size (here identified as species with a mean body mass greater than $21 \mathrm{~kg}$ ). This is important because $21 \mathrm{~kg}$ represents a threshold value among carnivorans at which the dietary pattern changes from species feeding mainly or exclusively on prey with a body mass much less than their own to species that feed mainly or exclusively on prey of equal body mass or greater than their own (Carbone et al. 1999). This is a general energetic constraint and is not limited to carnivorans. Both chimpanzees and early hominins exceed this mass threshold, yet chimpanzees do not exploit large-bodied prey, whereas early hominins did (although when this began is a moot point, as outlined in the paper). This means that, from the carnivoran perspective, chimpanzees are not carnivores, merely animals that occasionally exploit animal resources for reasons that may have nothing to do with nutrition. Early hominins, on the other hand, would be considered carnivores, although this perspective is silent on the amount of animal protein ingested relative to other foodstuffs. Important to note, in agreement with the Thompson et al. paper, this means that chimpanzees are an unsuitable model for investigating the HPP and the HPP cannot be extrapolated from chimpanzee feeding behavior. Therefore, in my carnivoran-biased view, Thompson et al. are quite correct in proposing a new paradigm, divorced from the chimpanzee-based model.

As carnivores, early hominins shared a trait that gave them a competitive advantage over contemporary carnivorans: they had available to them a diversity of fallback foods, including vegetable matter as well as animal protein not obtained from mammals. Carnivoran mortality is often associated with a reduction in the amount of available animal protein during times of environmental stress. Early hominins, on the other hand, had less risk of starvation than other large-bodied carnivores, as they could sustain their existence on a diet that did not include protein from large mammals. This gave early hominins a competitive edge that would have allowed them to increasingly encroach on carnivoran ecospace, eventually leading to a collapse of the large carnivoran guild in eastern Africa (Werdelin and Lewis 2013). It is further clear that the more spectacular phase of this collapse, dated to ca. $2 \mathrm{Ma}$, was the tipping point of a long-term trend of increasing hominin competition with carnivorans, to the detriment of the latter. Issues of habitat change and the risk of confrontation are important in this context. In the moment of confrontation the risk would have been to the hominins, but on an evolutionary time scale the risk was to the carnivorans. A discussion of these important issues is beyond the scope of this commentary, however.

Some aspects of carnivoran evolution in Africa mentioned in the paper should be clarified. First, although the record shows a number of first appearances of carnivoran species at around 3.6 Ma (or slightly earlier given the latest dates of some critical sites), this can largely be attributed to poor sampling of the record prior to this time and to the "Laetoli effect," in which one of the richest sites for Pliocene carnivorans in eastern Africa is also one of the earliest, greatly inflating the number of new species in its time slice. This applies to carnivorans, but one must assume that it applies equally to herbivores. Second, bone cracking as an advanced adaptation did not first appear in Africa ca. 3.6 Ma (with Crocuta). It was present in Africa from at least the late Miocene. In fact, specific dental adaptations had evolved as a synapomorphy of all derived Hyaenidae by $11 \mathrm{Ma}$ at least and are thus shared by all African hyenas, living and extinct, with the exception of the aardwolf, Proteles (Ferretti 2007; Werdelin and Solounias 1991). Thus, the hyenid fossil record does not support ecological change around 3.6 Ma that involved increased scavenging opportunities. If there was any specific time at which early hominin exploitation of inside-bone resources became possible, this would have been due to changes that allowed these early hominids access to a resource that hyenas already were exploiting.

In summary, from the carnivoran perspective the hypothesis of Thompson et al. regarding the HPP represents a significant and important change in focus in the study of the process of "dietary hominization." It more clearly places hominins as a marginal but significant member of the large carnivore guild and helps place prior hypotheses of carnivore extinction in east Africa (Werdelin and Lewis 2013) in a broader context. Finally, the authors speak of a new methodology of field research taking an archaeological approach to questions thought purely paleontological. From the carnivoran perspective I would also (self-servingly) encourage researchers to adopt a more broadly biological approach to questions thought purely anthropological. In the final reckoning, it is evolution that drives it all.

\section{Richard Wrangham}

Peabody Museum, Harvard University, 11 Divinity Avenue, Cambridge, Massachusetts 02138, USA (wrangham@fas.harvard .edu). 6 II 18

Thompson et al. constructively propose that a critical intermediate step between hominins killing small and large prey was the exploitation of large-animal carcasses for marrow and brains. The key activity, percussive fat gathering, would have differed importantly from eating meat.

The idea that percussive fat gathering would have been a regular Pliocene activity seems plausible and heuristically valuable. As Thompson et al. note, it would have been a relatively low-cost and high-benefit activity. Marrow and bone persist longer, in better condition for a consumer, than outsidebone products and would therefore have been more readily available. Percussive technology has arisen several times in 
nonhuman primates, and chimpanzees readily eat marrow (and, it should be noted, brains; Goodall 1986).

I suggest an additional argument not mentioned by Thompson et al. The raw meat of large adult animals was not necessarily very valuable. When chimpanzees kill infant prey or infant chimpanzees, they normally eat them (Arcadi and Wrangham 1999; Stanford 1998). By contrast, no cases of chimpanzees eating adult chimpanzee meat have been recorded, despite dozens of opportunities to do so (Wilson et al. 2014). When victims are killed in a territorial boundary area, the lack of meat-eating could be explained by the killers being motivated to return to the safety of the more central part of their community range. That explanation does not apply to victims killed within a community, however. Chimpanzees are evidently not averse to cannibalism or to tasting their adult victims, as they have occasionally ingested small amounts of blood from open wounds. These points suggest that the reasons why chimpanzees avoid eating the meat of adults are "economic." Difficulties could include not only meat being difficult to detach but also its having a low value due to its being difficult to chew raw, more liable to pathogens, and putatively less easily digested than the meat of younger animals (due to higher levels of collagen). This could also explain why chimpanzees sometimes leave the carcasses of medium-sized prey (monkeys or ungulates up to about $10 \mathrm{~kg}$ ) that they have killed (Goodall 1986). In the early stages of exploiting large carcasses, therefore, "inside-bone" fat may have been routinely preferable to meat because the meat could have been low value. Investigation of the costs and benefits of chewing the raw meat of large wild adults would be helpful to assess this issue for the early stages of increased carnivory. Later, the adoption of cooking would have increased the relative benefits of meateating compared to fat-eating (Wrangham 2017). In short, the relative nutritional value of meat compared to fat may have been lower prior to the adoption of cooking compared to afterward.

If percussive fat gathering was an important strategy for Pliocene hominins, brains would have had a different significance from marrow. The fat content of mammalian brains never changes significantly from around $50 \%-60 \%$, whereas the fat content in ungulate marrow varies over the year between about $20 \%$ (when the animal is starving) to more than 90\% (Lupo 1998; Wrangham 2017). This means that hominins are expected to have exhibited a distinct seasonal pattern in the use of these resources: marrow should have been eaten more during seasons of high ungulate quality (i.e., good grazing conditions). Brains would always have been valuable foods, as they are among chimpanzees, which often prioritize eating them (Goodall 1986). They should have been particularly important targets during bad periods, when marrow quality was poor.

If fat was a significantly higher quality and more valuable food than meat, especially prior to cooking, hominins may have been faced with the need to cut into carcasses more because meat was an obstruction than because it was a desirable item. Is it possible that early butchery could have reflected the need to cut meat away to reach areas of fat as much as to exploit the meat itself? Fat areas were not confined to withinbone regions. For instance, in impala Aepyceros melampus the volume of kidney fat varies widely over the year and is closely correlated with the percentage of fat in marrow (Dunham and Murray 1982). Hominins' ability to reach fat both outside and within bones might have been an important stimulus for using flakes.

A final point is a sidenote on a specific datum cited from Kimbel and Villmoare (2016), who reported the striking claim that australopithecines had a brain size about 30\% larger than a chimpanzee. The $30 \%$ figure applies only to Pan troglodytes troglodytes, which according to Isler et al. (2008) has the smallest recorded endocranial volume (ECV) among chimpanzee subspecies (female: $347.2 \mathrm{cc}, n=41$; male: $378.9 \mathrm{cc}$, $n=38$ ). For P. t. schweinfurthii, measurements of adult ECV from Kibale National Park in Uganda (five female, four male), combined with data from Isler et al. (2008; two female, two male) yield higher means (female: $362.9 \mathrm{cc}, n=7$; male: $436.9 \mathrm{cc}, n=6$ ). The mean ECV of females and males is thus $363.1 \mathrm{cc}$ for P. t. troglodytes versus $399.9 \mathrm{cc}$ for P. t. schweinfurthii. If australopithecines are given a mean ECV of $470 \mathrm{cc}$ (Kimbel and Villmoare 2016), their ECVs are larger than chimpanzees by $29.5 \%$ for P. t. troglodytes, versus only $17.5 \%$ for P. t. schweinfurthii. Although the sample size for P. t. schweinfurthii is small, this note suggests that it is premature to conclude that australopithecines had brains 30\% larger than those of chimpanzees in general.

\section{Reply}

This contribution aimed to establish a new theoretical framework and open empirical research avenues on a major dietary transition in hominin evolution. Our approach was twofold: (1) critical deconstruction of the terms and underlying assumptions that have limited previous discourse and (2) presentation of a new model for this dietary transition, with test implications, that relocates percussive within-bone nutrient extraction to an explicitly central position. We then offered a road map for future work that must be interdisciplinary in nature. We were thus pleased to see responses from a range of perspectives, including archaeology, primatology, and paleoecology-paleontology. Here, we reply to issues the commentators have thoughtfully raised concerning the nature of the empirical record, the methodological tool kits we must develop to advance research in this area, and the theoretical framing of our percussion scavenging model.

\section{Pattern and Constraint of the Empirical Record}

Braun emphasizes the absence of large archaeological and zooarchaeological assemblages prior to $\sim 2.0 \mathrm{Ma}$, also noting 
how (so far) there are no reported instances of single-carcass butchery events dating to this time. This archaeological invisibility may adequately be explained by scarcity and lack of investigation of appropriate-aged deposits or by absence of the behavior. This directly addresses one of the main archaeological hurdles, which is how to interpret absence of evidence at a given time period. In cases where the emergence of something new is under investigation, verifying its absence is as critical as documenting its presence. This places a heavy burden of proof on researchers to demonstrate that their methods are adequate for finding the requisite evidence, if such evidence does in fact exist.

We argue that work done thus far in paleoanthropology to understand the transition to large-game foraging does not yet meet this standard, but it is equally important to recognize that even the most comprehensive new survey methods may not be enough. The earliest interactions of hominins with carcasses may have initially been constrained by environmentsthus, specific depositional settings - where fossils simply may not preserve. They may have been conducted with no tools, with perishable tools, or with tools that do not preserve diagnostic traces. This is an old problem in paleoanthropology; some of the milestones in our evolution may have occurred well outside the boundaries of the small localities from which we derive most fossil data. However, a general pattern is still discernable. We take a similarly optimistic view of the Pliocene archaeological record but argue that its pattern will not be discernable while the field is dominated by individual and often serendipitous discoveries of the presence of a given behavior (flaked stone tool use, carcass butchery, etc.). Now is the time to begin the much harder task of systematically demonstrating the timing and location of both their presence and absence.

Shea notes that we may need to reconsider other key assumptions, as there is no a priori reason to consider that the earliest use for flaked stone tools was in fact for butchery. Because bones and stones preserve better than other classes of evidence, and because sometimes they are found in association, an undertheorized coevolutionary explanation has been forged. What we imagine early hominins doing with pounding tools is similarly constrained by our modern interpretive models. Shea argues that knowing essentially nothing about early percussive tool use in our own lineage does not give us license to use living nonhuman primates as the default model. Instead, he looks to percussive behaviors unique to hominins as sufficient explanation for their emergence. This does not, however, negate the value of extant primate studies in establishing what is and is not unique within our lineage.

\section{Methodology}

The commentators raise rightful concerns with a departure from traditional approaches to paleontological and archaeological survey of Pliocene deposits. Some are inherently practical. How can we justify dedicating large quantities of field time to documenting minute traces that may not ultimately be informative? Where can we store all the additional rocks and fossils that must be collected? Others are more abstract. How can we identify subtle anthropogenic traces in the field, and discern these from other traces, to guide collection? Where on a vast landscape of possibilities should we look for them?

Pante takes a pessimistic view of the practical obstacle of identifying traces associated with within-bone nutrient extraction, emphasizing the ongoing uphill climb that taphonomists face in interpreting behavioral traces on bone and stone surfaces. However, in reiterating our assertion that within-bone nutrient extraction has been a persistent but underemphasized element in this work, he offers a nugget of optimism. Many of the new technical and inferential approaches, such as 3D scanning and Bayesian modeling, have yet to be comprehensively applied to such traces. These approaches offer fine-resolution data that can be subjected to more objective and probabilistic statements on the agent surface modification. By placing percussion traces as central test implications in a new model of the transition to large-carcass foraging, we hope that such work will receive the attention it merits. It is an exciting moment in taphonomy; even between the time of Pante's writing and this reply, percussion damage to bone has begun to enter into these analyses (Yravedra et al. 2018).

This rapid escalation of new experimental and analytical work reflects a renewed, broadly applicable cycle of taphonomic investigation (James and Thompson 2015). As during previous cycles, data from Plio-Pleistocene assemblages have been instrumental in advancing this work, but now there is a key difference. This one is fueled by questions that, until recently, few researchers would have thought to ask (McPherron et al. 2010). The DIK-55 marks have been controversial, but they have played a critical role in stimulating a new arena of research. First, there is recognition that new objective and probabilistic techniques for assigning agent to surface modification need to be developed for these challenging fossil assemblages, and as Pante notes, several research groups are vigorously making headway. Second, fieldwork targeting preOldowan sediments is required, and that fieldwork must be equipped with new methods, largely developed in archaeology, that target fragmented fossil bone ignored by past field studies. Finally, we need fresh theoretical perspectives to help guide this research, and as the commentators note, our paper tackles this need.

The DIK-55 marks offered impetus for researchers to revisit other collections that long resided in the literature as early instances of stone-tool-assisted butchery (Sahle et al. 2017). More important, they have stimulated a critical rethinking of methods of identifying bone surface modifications that wereand still are - common fare in zooarchaeology. This crisis of faith in bone surface modification studies, at least when applied to small pre-Oldowan samples, has exposed several key problems. For example, there has been an overreliance on expert knowledge systems in mark identification (Harris et al. 2017), which penetrates even to the level of individuals trained in the same research tradition (Domínguez-Rodrigo et al. 
2017). Expert knowledge of blind-tested analysts was once the accepted approach, but with very small mark samples in contexts where there is ambiguity about which tools were used, it is clear that new objective and probabilistic approaches are needed. These may include, for example, machine learning (Domínguez-Rodrigo and Baquedano 2018) and Bayesian inference (Harris et al. 2017; Otárola-Castillo et al. 2018) to reduce as much as possible the influence of individual experts in mark diagnosis.

These approaches also address a second problem: marks have traditionally been diagnosed in a binary manner (either it "is" or it "is not" a cut mark, trample mark, tooth mark, etc.). By coding suites of characteristics of marks, probability can be assigned to the overall goodness of fit against modern experimental analogues. The next step will be to establish - and quantify - the physical variables that underlie production of these characteristics. Lithic analysts have developed tools for standardizing the experimental production of stone artifacts so that they know how changes in striking angle, force, core morphology, and other variables affect the outcome of a knapping event (Dibble and Rezek 2009; Rezek et al. 2011). In taphonomy, we remain decades behind in understanding and constraining comparable individual variables (James 2018).

Pante and Shea both carefully articulate the many places such work has yet to go before taphonomists are fully equipped to identify the traces we expect to be associated with the transition to the HPP. Shea emphasizes the importance of agreement not only in advancing the science of paleoanthropology but in demonstrating epistemological coherence outside of our discipline. Pante focuses on specific attributes of the marked fossils from DIK-55 to argue that until we have better methodological tools for untangling the traces left by different agents, we cannot accept this as definitive evidence of stone-tool-assisted butchery in the Pliocene. We concur that advances in taphonomic method must be an integrated part of research into the origins of the HPP, and we argue that therefore it is equally premature to assign a new interpretation of the marks until we have all those tools at hand. Fortunately, and thanks to the efforts of several research groups, that future seems increasingly near.

\section{Theoretical Framing}

Werdelin situates the transition to the HPP within a "carnivoran-view" perspective of the encroachment of hominins into their competitive ecospace between $\sim 3.6$ and $2.0 \mathrm{Ma}$. He argues that over evolutionary timescales, the flexible nature of hominin diets were deadly to carnivorans, even if individual encounters were deadlier to hominins. Thus, the transition to the HPP should be heralded by a general increase in dietary breadth and flexibility, both of which have test implications for lines of evidence such as zooarchaeology, dietary isotopes, and dental microwear. Important for behavioral models, hominins need not have engaged in frequent direct competition over carcasses to have waged a war of slow attrition that ultimately facilitated even more regular access. Thus, Werdelin widens our view of available evidence from the perspective of changes in the hominin lineage to that of entire ecosystem transformations.

The impact of hominin competition on the carnivore guild is also worth considering in light of the variability selection hypothesis, which is typically applied to explanations of speciation and innovation within the hominin lineage itself (Potts and Faith 2015). It is well known that large-bodied carnivores are most vulnerable to extinction during periods of ecosystem change (Ripple et al. 2014) and that generalists typically fare better than specialists (Clavel, Julliard, and Devictor 2010). The implications are that some hominins, as the ultimate generalists, have shaped the course of faunal communities even as they themselves have adapted to environmental change. However, in advocating for a "more broadly biological approach," Werdelin narrows his own view to exclude other key advantages unique to the hominin lineage: technology, culture, and expanded forms of cooperation.

Biological sciences alone cannot explain the origins and evolution of a species the ultimate adaptation of which is cultural, and we argue for an approach that fuses biology and culture in an effective manner. We do not yet know when these features evolved and became significant, but together they gave hominins a potent lethality against prey and competitors. As we note in our paper, the hand of Australopithecus afarensis already suggests regular tool use. Fallback foods often require relatively intense extractive foraging, and tool use may have been the key pathway into the efficient use of those foods.

Werdelin also offers important clarification on the emergence of bone-cracking morphology in some carnivoran lineages, noting that in Africa such morphologies have been present since $11 \mathrm{Ma}$. Thus, hominin entry into the bone-cracking niche was not a response to increased scavenging opportunities but rather a shortcut in the evolutionary pathway necessary to access within-bone nutrients. The niche was already occupied, and this makes intrusion by hominins all the more impressive. Again, a key insight is that the intrusion into this bone-cracking niche was via technology and culture, not biology, and this percussive technology may have ultimately been the preadaptation to stone tool technology itself.

Visalberghi offers a more proximate perspective, arguing for how preferences may have developed for specific carcass portions (within-bone vs. outside-bone nutrients). She uses evidence from outside the ape clade to argue that small prey exploitation is requisite to developing taste awareness of withinbone nutrients, because in small prey these can be exploited without tools. Energetics form an important part of this argument, because the costs of chewing raw meat are relatively high (Zink and Lieberman 2016). From this, Visalberghi offers an additional use for pounding tools as meat processors, which would have expanded their utility to outside-bone nutrients and made meat more attractive on both small- and large-bodied prey.

Wrangham takes a similar stance on the value of meat versus softer parts, citing chimpanzee data showing that meat from 
infant chimpanzees is eaten, but meat from adults - the only putative "large prey" of other chimpanzees - is avoided. Wrangham argues that this is because meat is not per se an energetically profitable resource (in his view, it did become profitable after the advent of cooking). A similar critique has been leveled at this assumption by researchers who note the very low fat content of wild game meat and the metabolic difficulties that overconsumption would convey to hominin consumers (Speth 2010). The low profitability of meat is a critical point because its purported superiority in terms of "dietary quality" is perhaps one of the most dearly held stances in paleoanthropology. Wrangham even suggests that early cutting tools were used primarily as a means of removing the largely useless meat in order to access fat-rich bones and organs.

Using a similar energetic argument, Braun notes that not all small prey are fat poor and fast moving. They can also be subject to seasonality effects in both their costs and returns. Specifically, aquatic resources are more easily exploited during dry seasons, when terrestrial animals are most stressed and their fat content lowest. Similarly, Wrangham notes that brain experiences much less seasonal fluctuation in fat content than does marrow, although it occurs in overall smaller quantities (Lupo 1998). Together, these arguments reinforce comments by Werdelin that it was the generalist and flexible dietary strategy of early hominins - although we add to this technology and culture - that afforded them their evolutionary edge. It is perhaps this very complexity that has made it so difficult for paleoanthropologists to model-or indeed even agree upon a definition for-the origins of the HPP. With a suite of emerging tool kits and interdisciplinary intersections of data, we are optimistic that Pliocene deposits will soon begin to divulge their more subtle traces of this behavior.

-Jessica C. Thompson, Susana Carvalho, Curtis W. Marean, and Zeresenay Alemseged

\section{References Cited}

Aiello, Leslie C., and Susan C. Antón. 2012. Human biology and the origins of Homo: an introduction to supplement 6. Current Anthropology 53(suppl. 6):S269-S277.

Alemseged, Zeresenay. 2015. Stable isotopes serving as a checkpoint. Proceedings of the National Academy of Sciences 112(40):12232-12233.

Ambrose, Stanley H. 2001. Paleolithic technology and human evolution. Science 291(5509):1748-1753.

Antón, Susan C., Richard Potts, and Leslie C. Aiello. 2014. Evolution of early Homo: an integrated biological perspective. Science 345(6192):1236828.

Arcadi, Adam C., and Richard W. Wrangham. 1999. Infanticide in chimpanzees: review of cases and a new within-group observation from the Kanyawara study group in Kibale National Park. Primates 40:337-351. [RW]

Archer, W., D. R. Braun, J. W. Harris, J. T. McCoy, and B. G. Richmond. 2014. Early Pleistocene aquatic resource use in the Turkana Basin. Lournal of Human Evolution 77:74-87. [DRB]

Behrensmeyer, Anna K., Susan M. Kidwell, and Robert A. Gastaldo. 2000. Taphonomy and paleobiology. Paleobiology 26(suppl. 4):103-147. [DRB]

Behrensmeyer, Anna K., and Kaye E. Reed. 2013. Reconstructing the habitats of Australopithecus: paleoenvironments, site taphonomy, and faunas. In The paleobiology of Australopithecus. K. E. Reed, J. G. Fleagle, and R. E. Leakey, eds. Pp. 41-60. Dordrecht: Springer.
Benito-Calvo, A., A. Arroyo, L. Sánchez- Romero, M. C. Pante, and I. de la Torre. 2018. Quantifying 3D micro-surface changes on experimental stones used to break bones and their implications for the analysis of Early Stone Age pounding tools. Archaeometry 60(3):419-436. [DRB, MP]

Benito-Calvo, Alfonso, Susana Carvalho, Adrian Arroyo, Tetsuro Matsuzawa, and Ignacio de la Torre. 2015. First GIS analysis of modern stone tools used by wild chimpanzees (Pan troglodytes verus) in Bossou, Guinea, West Africa. PLoS ONE 10(3):e0121613.

Binford, L. R. 1981. Bones: ancient men and modern myths. New York: Academic. . 1988. Fact and fiction about the Zinjanthropus floor: data, arguments, and interpretations. Current Anthropology 29:123-135. [MP]

Biro, D., S. Carvalho, and T. Matsuzawa. 2010. Tools, traditions, and technologies: interdisciplinary approaches to chimpanzee nut-cracking. In The mind of the chimpanzee: ecological and experimental perspectives. Elizabeth V. Lonsdorf, Stephen R. Ross, and Tetsuro Matsuzawa, eds. Pp. 141-155. Chicago: University of Chicago Press. [DRB]

Blumenschine, R. J. 1986. Carcass consumption sequences and the archaeological distinction of scavenging and hunting. Lournal of Human Evolution 15:639-659.

1989. A landscape taphonomic model of the scale of prehistoric scavenging opportunities. Journal of Human Evolution 18:345-371.

- 1995. Percussion marks, tooth marks, and experimental determinations of the timing of hominid and carnivore access to long bones at FLK Zinjanthropus, Olduvai Gorge, Tanzania. Journal of Human Evolution 29:21-51. [MP]

Blumenschine, R. J., J. A. Cavallo, and S. D. Capaldo. 1994. Competition for carcasses and early hominid behavioral ecology: a case study and conceptual framework. Journal of Human Evolution 27(1):197-213. [DRB]

Blumenschine, R. J., and T. C. Madrigal. 1993. Variability in long bone marrow yields of East African ungulates and its zooarchaeological implications. Journal of Archaeological Science 20:555-587.

Blumenschine, R. J., and M. M. Selvaggio. 1988. Percussion marks on bone surfaces as a new diagnostic of hominid behaviour. Nature 333:763-765. [MP]

Blumenschine, Robert J., Henry T. Bunn, Valerius Geist, Fumiko IkawaSmith, Curtis W. Marean, Anthony G. Payne, John Tooby, and Nikolaas J. van der Merwe. 1987. Characteristics of an early hominid scavenging niche. Current Anthropology 28:383-407, comments and reply.

Blumenschine, Robert J., Curtis W. Marean, and Salvatore D. Capaldo. 1996. Blind tests of inter-analyst correspondence and accuracy in the identification of cut marks, percussion marks, and carnivore tooth marks on bone surfaces. Lournal of Archaeological Science 23:493-507.

Blumenschine, Robert J., Ian G. Stanistreet, Jackson K. Njau, Marion K. Bamford, Fidelis T. Masao, Rosa M. Albert, Harald Stollhofen, et al. 2012. Environments and hominin activities across the FLK Peninsula during Zinjanthropus times (1.84 Ma), Olduvai Gorge, Tanzania. Lournal of $\mathrm{Hu}$ man Evolution 63:364-383.

Boesch, C., and H. Boesch. 1990. Tool use and tool making in wild chimpanzees. Folia Primatologica 54:86-99.

Brain, C. K. 1981. The hunters or the hunted? an introduction to African cave taphonomy. Chicago: University of Chicago Press.

Braun, D. R., J. W. K. Harris, and D. N. Maina. 2009. Oldowan raw material procurement and use: evidence from the Koobi Fora Formation. Archaeometry 51(1):26-42.

Braun, David R., John W. K. Harris, Naomi E. Levin, Jack T. McCoy, Andy I. R. Herries, Marion K. Bamford, Laura C. Bishop, Brian G. Richmond, and Mzalendo Kibunjia. 2010. Early hominin diet included diverse terrestrial and aquatic animals 1.95 Ma in East Turkana, Kenya. Proceedings of the National Academy of Sciences 107(22):10002-10007.

Brochu, Christopher A., and Glenn W. Storrs. 2012. A giant crocodile from the Plio-Pleistocene of Kenya, the phylogenetic relationships of Neogene African crocodylines, and the antiquity of Crocodylus in Africa. Iournal of Vertebrate Paleontology 32(3):587-602.

Bunn, H. T. 1994. Early Pleistocene hominid foraging strategies along the ancestral Omo River at Koobi Fora, Kenya. Journal of Human Evolution 27:247-266.

Bunn, Henry T. 2007. Meat made us human. In Evolution of the human diet: the known, the unknown, and the unknowable. P. Ungar, ed. Pp. 191-211. Oxford: Oxford University Press.

Butynski, Thomas M. 1982. Vertebrate predation by primates: a review of hunting patterns and prey. Lournal of Human Evolution 11(5):421-430.

Capaldo, S. D. 1997. Experimental determinations of carcass processing by PlioPleistocene hominids and carnivores at FLK 22 (Zinjanthropus), Olduvai Gorge, Tanzania. Journal of Human Evolution 33:555-597. [MP] 
Capaldo, S. D., and R. J. Blumenschine. 1994. A quantitative diagnosis of notches made by hammerstone percussion and carnivore gnawing on bovid long bones. American Antiquity 59:724-748. [MP]

Carbone, C., G. M. Mace, S. C. Roberts, and D. W. Macdonald. 1999. Energetic constraints on the diet of terrestrial carnivores. Nature 402:286-288. [LW]

Carmody, Rachel N., and Richard W. Wrangham. 2009. The energetic significance of cooking. Journal of Human Evolution 57(4):379-391.

Caruana, Matthew V., Susana Carvalho, David R. Braun, Darya Presnyakova, Michael Haslam, Will Archer, Rene Bobe, and John W. K. Harris. 2014 Quantifying traces of tool use: a novel morphometric analysis of damage patterns on percussive tools. PLOS ONE 9(11):e113856.

Carvalho, Susana, Dora Biro, Eugénia Cunha, Kimberley Hockings, William C. McGrew, Brian G. Richmond, and Tetsuro Matsuzawa. 2012. Chimpanzee carrying behaviour and the origins of human bipedality. Current Biology 22(6):R180-R181.

Carvalho, Susana, Dora Biro, William C. McGrew, and Tetsuro Matsuzawa. 2009. Tool-composite reuse in wild chimpanzees (Pan troglodytes): ar chaeologically invisible steps in the technological evolution of early hominins? Animal Cognition 12(1):103-114.

Carvalho, Susana, Eugénia Cunha, Cláudia Sousa, and Tetsuro Matsuzawa. 2008. Chaînes opératoires and resource-exploitation strategies in chimpanzee (Pan troglodytes) nut cracking. Journal of Human Evolution 55(1):148 163.

Cavallo, J. A., and R. J. Blumenschine. 1989. Tree-stored leopard kills expanding the hominid scavenging niche. Lournal of Human Evolution 18:393-399

Cerling, Thure E., Fredrick Kyalo Manthi, Emma N. Mbua, Louise N. Leakey, Meave G. Leakey, Richard E. Leakey, Francis H. Brown, Frederick E. Grine, John A. Hart, and Prince Kaleme. 2013. Stable isotope-based diet reconstructions of Turkana Basin hominins. Proceedings of the National Academy of Sciences 110(26):10501-10506.

Clark, J. L., and I. Plug. 2008. Animal exploitation strategies during the south African middle stone Age: Howiesons Poort and post-Howiesons Poort fauna from Sibudu Cave. Journal of Human Evolution 54(6):886-898. [DRB]

Clavel, Joanne, Romain Julliard, and Vincent Devictor. 2010. Worldwide decline of specialist species: toward a global functional homogenization? Frontiers in Ecology and the Environment 9(4):222-228.

Codding, Brian F., and Douglas W. Bird. 2015. Behavioral ecology and the future of archaeological science. Iournal of Archaeological Science 56:9-20.

Dart, R. 1953. The predatory transition from ape to man. International Anthropological and Linguistic Review 1:201-218.

Davidson, Ian, and Sue Solomon. 1990. Was OH 7 the victim of a crocodile attack? In Problem solving in taphonomy: archaeological and palaeontological studies from Europe, Africa and Oceania, vol. 2. S. Solomon, I. Davidson, and D. Watson, eds. St. Lucia: Tempus.

DeCasien, Alex R., Scott A. Williams, and James P. Higham. 2017. Primate brain size is predicted by diet but not sociality. Nature Ecology \& Evolution 1:0112.

de Heinzelin, J., J. D. Clark, T. D. White, W. K. Hart, P. Reene, G. WoldeGabriel, Y. Beyene, and E. Vrba. 1999. Environment and behavior of 2.5-million-year-old Bouri hominids. Science 284:625-635.

Delagnes, Anne, and Hélène Roche. 2005. Late Pliocene hominid knapping skills: the case of Lokalalei 2C, West Turkana, Kenya. Journal of Human Evolution 48(5):435-472.

de la Torre, I., A. Benito-Calvo, A. Arroyo, A. Zupancich, and T. Proffitt. 2012. Experimental protocols for the study of battered stone anvils from Olduvai Gorge (Tanzania). Journal of Archaeological Science 40(1):313-332. [DRB]

Dibble, Harold L., and Zeljko Rezek. 2009. Introducing a new experimental design for controlled studies of flake formation: results for exterior platform angle, platform depth, angle of blow, velocity, and force. Journal of Archaeological Science 36:1945-1954.

Diez-Martín, Fernando, Policarpo Sánchez, Manuel Domínguez-Rodrigo, Audax Mabulla, and Rebeca Barba. 2009. Were Olduvai Hominins making butchering tools or battering tools? analysis of a recently excavated lithic assemblage from BK (Bed II, Olduvai Gorge, Tanzania). Iournal of Anthropological Archaeology 28(3):274-289.

Domínguez-Rodrigo, M. 2009. Are all Oldowan Sites palimpsests? if so, what can they tell us about Hominid carnivory? In Interdisciplinary approaches to the Oldowan. Erella Hovers and David R. Braun, eds. Pp. 129-147. Dordrecht: Springer. [DRB]
Domínguez-Rodrigo, M., and L. Alcalá. 2016. 3.3-million-year-old stone tools and butchery traces? more evidence needed. PaleoAnthropology 2016:4653.

Domínguez-Rodrigo, M., R. Barba, and Charles P. Egeland. 2007. Deconstructing Olduvai: a taphonomic study of the Bed I sites. Dordrecht: Springer.

Domínguez-Rodrigo, M., H. T. Bunn, A. Z. P. Mabulla, E. Baquedano, D. Uribelarrea, A. Pérez-González, A. Gidna, et al. 2014. On meat eating and human evolution: a taphonomic analysis of BK4b (Upper Bed II, Olduvai Gorge, Tanzania), and its bearing on hominin megafaunal consumption. Quaternary International 322:129-152.

Domínguez-Rodrigo, M., S. de Juana, A. B. Galán, and M. Rodríguez. 2009. A new protocol to differentiate trampling marks from butchery cut marks. Journal of Archaeological Science 36(12):2643-2654.

Domínguez-Rodrigo, M., and T. R. Pickering. 2017. The meat of the matter: an evolutionary perspective on human carnivory. Azania 52(1):4-32.

Domínguez-Rodrigo, M., T. R. Pickering, and H. T. Bunn. 2011. Reply to McPherron et al.: doubting Dikika is about data, not paradigms. Proceedings of the National Academy of Sciences 108(21):E117-E117. [DRB]

Domínguez-Rodrigo, M., T. Pickering, and H. T. Bunn. 2012. Experimental study of cut marks made with rocks unmodified by human flaking and its bearing on claims of 3.4-million-year-old butchery evidence from Dikika, Ethiopia. Journal of Archaeological Science 39:205-214.

Domínguez-Rodrigo, M., T. R. Pickering, S. Semaw, and M. J. Rogers. 2005 Cutmarked bones from Pliocene archaeological sites at Gona, Afar, Ethiopia: Implications for the function of the world's oldest stone tools. Journal of Human Evolution 48(2):109-121.

Domínguez-Rodrigo, M., and J. Yravedra. 2009. Why are cut mark frequencies in archaeofaunal assemblages so variable? a multivariate analysis. Journal of Archaeological Science 36:884-894.

Domínguez-Rodrigo, Manuel. 2001. A study of carnivore competition in riparian and open habitats of modern savannas and its implications for hominid behavioral modelling. Journal of Human Evolution 40(2):77-98.

Domínguez-Rodrigo, Manuel, and Enrique Baquedano. 2018. Distinguishing butchery cut marks from crocodile bite marks through machine learning methods. Scientific Reports 8(1):5786.

Domínguez-Rodrigo, Manuel, Palmira Saladié, Isabel Cáceres, Rosa Huguet, José Yravedra, Antonio Rodríguez-Hidalgo, Patricia Martín, et al. 2017. Use and abuse of cut mark analyses: the Rorschach effect. Lournal of Archaeological Science 86:14-23.

Dunbar, Robin. 2016. Human evolution: our brains and our behavior. New York: Oxford University Press. [JJS]

Dunham, K. M., and Martyn G. Murray. 1982. The fat reserves of impala, Aepyceros melampus. African Journal of Ecology 20:81-87. [RW]

Fahy, Geraldine E., Michael Richards, Julia Riedel, Jean-Jacques Hublin, and Christophe Boesch. 2013. Stable isotope evidence of meat eating and hunting specialization in adult male chimpanzees. Proceedings of the $\mathrm{Na}$ tional Academy of Sciences 110(15):5829-5833.

Ferraro, J. V., K. M. Binetti, L. A. Wiest, D. Esker, L. E. Baker, and S. L. Forman. 2018. Contesting early archaeology in California. Nature 554 (7691):E1. [DRB]

Ferraro, Joseph V., Thomas W. Plummer, Briana L. Pobiner, James S. Oliver, Laura C. Bishop, David R. Braun, Peter W. Ditchfield, et al. 2013. Earliest archaeological evidence of persistent hominin carnivory. PLOS ONE 8(4): e62174.

Ferretti, Marco P. 2007. Evolution of bone-cracking adaptations in hyaenids (Mammalia, Carnivora). Swiss Journal of Geosciences 100(1):41-52. [LW]

Gaillard, Claire, Mukesh Singh, Anne Dambricourt Malassé, Vipnesh Bhardwaj, Baldev Karir, Amandeep Kaur, Surinder Pal, et al. 2016. The lithic industries on the fossiliferous outcrops of the Late Pliocene Masol Formation, Siwalik Frontal Range, northwestern India (Punjab). Comptes Rendus Palevol 15(3):341-357.

Galef, B. G., Jr. 1996. Food selection: problems in understanding how we choose foods to eat. Neuroscience and Biobehavioral Reviews 20(1):67-73. [EV]

Gettler, Lee T. 2010. Direct male care and hominin evolution: why male-child interaction is more than a nice social idea. American Anthropologist 112 (1):7-21.

Goodall, Jane. 1986. The chimpanzees of Gombe: patterns of behavior. Cambridge, MA: Harvard University Press. [RW]

Grabowski, Mark, Kevin G. Hatala, William L. Jungers, and Brian G. Richmond. 2015. Body mass estimates of hominin fossils and the evolution of human body size. Iournal of Human Evolution 85:75-93. 
Gumert, M. D., and K. S. Malaivijitnond. 2009. The physical characteristics and usage patterns of stone axe and pounding hammers used by long-tailed macaques in the Andaman Sea region of Thailand. American Journal of Primatology 71(7):594-608.

Hardy, Karen, Jennie Brand-Miller, Katherine D. Brown, Mark G. Thomas, and Les Copeland. 2015. The importance of dietary carbohydrate in human evolution. Quarterly Review of Biology 90(3):251-268.

Harmand, Sonia, Jason E. Lewis, Craig S. Feibel, Christopher J. Lepre, Sandrine Prat, Arnaud Lenoble, Xavier Boës, et al. 2015. 3.3-million-yearold stone tools from Lomekwi 3, West Turkana, Kenya. Nature 521(7552):310 315.

Harris, Jacob A., Curtis W. Marean, Kiona Ogle, and Jessica Thompson. 2017. The trajectory of bone surface modification studies in paleoanthropology and a new Bayesian solution to the identification controversy. Lournal of Human Evolution 110:69-81

Haslam, M. 2014. On the tool use behavior of the bonobo-chimpanzee last common ancestor, and the origins of hominine stone tool use. American Journal of Primatology 76(10):910-918. [DRB]

Haslam, M., M. D. Gumert, D. Biro, S. Carvalho, and S. Malaivijitnond. 2013. Use-wear patterns on wild macaque stone tools reveal their behavioural history. PLoS ONE 8(8):e72872. [DRB]

Haslam, M., A. Hernandez-Aguilar, V. Ling, S. Carvalho, I. de la Torre, A. DeStefano, A. Du, et al. 2009. Primate archaeology. Nature 460:339-344.

Hawkes, K. 1990. Why do men hunt? some benefits for risky choices. In Risk and uncertainty in tribal and peasant economies. E. Cashdan, ed. Pp. 145166. Boulder, CO: Westview. [DRB]

Hawkes, K., J. F. O'Connell, and N. G. B. Jones. 2014. More lessons from the Hadza about men's work. Human Nature 25(4):596-619. [DRB]

Hill, K. 1988. Macronutrient modifications of optimal foraging theory: an approach using indifference curves applied to some modern foragers. Human Ecology 16:157-197.

Hockings, Kimberley J., Matthew R. McLennan, Susana Carvalho, Marc Ancrenaz, Rene Bobe, Richard W. Byrne, Robin I. M. Dunbar, Tetsuro Matsuzawa, William C. McGrew, and Elizabeth A. Williamson. 2015. Apes in the Anthropocene: flexibility and survival. Trends in Ecology and Evolution 30(4):215-222.

Hohmann, G., and B. Fruth. 2008. New records on prey capture and meat eating by bonobos at Lui Kotale, Salonga National Park, Democratic Republic of Congo. Folia Primatologica 79(2):103-110.

Isler, Karin, E., Christopher Kirk, Joseph M. A. Miller, Gene A. Albrecht, Bruce R. Gelvin, and Robert D. Martin. 2008. Endocranial volumes of primate species: scaling analyses using a comprehensive and reliable data set. Journal of Human Evolution 55:967-978. [RW]

James, E. 2018. The relevance of basic science to stone tool use and meat eating: standardisation of bone surface modification methods and interpretations. $\mathrm{PhD}$ dissertation, University of Queensland, Brisbane.

James, Emma C., and Jessica C. Thompson. 2015. On bad terms: problems and solutions within zooarchaeological bone surface modification studies. Environmental Archaeology 20(1):89-103.

Johanson, Donald C. 2004. Lucy, thirty years later: an expanded view of Australopithecus afarensis. Journal of Anthropological Research 60(4):465486.

Josephs-Spaulding, Jonathan, Erik Beeler, and Om V. Singh. 2016. Human microbiome versus food-borne pathogens: friend or foe. Applied Microbiology and Biotechnology 100(11):4845-4863.

Kimbel, B. 2009. The origin of Homo. In The first humans: origin and early evolution of the genus Homo. F. E. Grine, J. G. Fleagle, and R. E. Leakey, eds. Pp. 31-37. New York: Springer.

Kimbel, William H., and Brian Villmoare. 2016. From Australopithecus to Homo: the transition that wasn't. Philosophical Transactions of the Royal Society B: Biological Sciences 371(1698).

Kitahara-Frisch, J., K. Norikoshi, and K. Hara. 1987. Use of a bone fragment as a step towards secondary tool use in captive chimpanzee. Primate Rep 18:33-37.

Langdon, J. 2006. Has an aquatic diet been necessary for hominin brain evolution and functional development? British Journal of Nutrition 96:7-17.

Lee-Thorp, Julia A., Matt Sponheimer, Benjamin H. Passey, Darryl J. de Ruiter, and Thure E. Cerling. 2010. Stable isotopes in fossil hominin tooth enamel suggest a fundamental dietary shift in the Pliocene. Philosophical Transactions of the Royal Society B: Biological Sciences 365(1556):33893396.

Lewis, M. E. 1997. Carnivoran paleoguilds of Africa: implications for hominid food procurement strategies. Journal of Human Evolution 32:257-288.
Lonsdorf, Elizabeth V. 2006. What is the role of mothers in the acquisition of termite-fishing behaviors in wild chimpanzees (Pan troglodytes schweinfurthii)? Animal Coonition 9(1):36-46.

Luncz, L. V., R. Mundry, and C. Boesch. 2012. Evidence for cultural differences between neighboring chimpanzee communities. Current Biology 22:922-926. [DRB]

Luncz, Lydia V., Tomos Proffitt, Lars Kulik, Michael Haslam, and Roman M. Wittig. 2016. Distance-decay effect in stone tool transport by wild chimpanzees. Philosophical Transactions of the Royal Society of London B: Biological Sciences 283(1845).

Luncz, Lydia V., Roman M. Wittig, and Christophe Boesch. 2015. Primate archaeology reveals cultural transmission in wild chimpanzees (Pan troglodytes verus). Philosophical Transactions of the Royal Society of London B: Biological Sciences 370(1682).

Lupo, K. 2012. On early hominin meat-eating and carcass acquisition strategies: still relevant after all these years? In Stone tools and fossil bones: debates in the archaeology of human origins. M. Domínguez-Rodrigo, ed. Pp. 115-151. Cambridge: Cambridge University Press.

Lupo, K. D. 1998. Experimentally derived extraction rates for marrow: implications for body part exploitation strategies of Plio-Pleistocene Hominid scavengers. Journal of Archaeological Science 25(7):657-676.

Madrigal, T. C., and R. J. Blumenschine. 2000. Preferential processing of high return rate marrow bones by Oldowan hominids: a comment on Lupo. Journal of Archaeological Science 27:739-741. [DRB]

Malassé, Anne Dambricourt, Anne-Marie Moigne, Mukesh Singh, Thomas Calligaro, Baldev Karir, Claire Gaillard, Amandeep Kaur, Vipnesh Bhardwaj, Surinder Pal, and Salah Abdessadok. 2016. Intentional cut marks on bovid from the Quranwala zone, 2.6 Ma, Siwalik Frontal Range, northwestern India. Comptes Rendus Palevol 15(3):317-339.

Marchant, Linda F, and William C McGrew. 2005. Percussive technology: chimpanzee baobab smashing and the evolutionary modeling of hominid knapping. In Stone knapping the necessary conditions for an uniquely hominin behaviour. Blandine Bril and Valentine Roux, eds. Pp. 341-350. McDonald Institute Monograph Series. Cambridge: McDonald Institute for Archaeological Research.

Marean, C. W., and L. Bertino. 1994. Intrasite spatial analysis of bone: subtracting the effect of secondary carnivore consumers. American Antiauity 59:748-768.

Marean, C. W., and C. E. Ehrhardt. 1995. Paleoanthropological and paleoecological implications of the taphonomy of a sabertooth's lair. Journal of Human Evolution 28:515-547.

Markham, A. Catherine, Laurence R. Gesquiere, Susan C. Alberts, and Jeanne Altmann. 2015. Optimal group size in a highly social mammal. Proceedings of the National Academy of Sciences 112(48):14882-14887.

McGrew, W. C. 2010. In search of the last common ancestor: new findings on wild chimpanzees. Philosophical Transactions of the Roval Society of London B: Biological Sciences 365(1556):3267-3276.

McGrew, William C. 2015. Why don't chimpanzees eat monitor lizards? African Primates 10:41-52.

McPherron, Shannon P., Zeresenay Alemseged, Curtis Marean, Jonathan G. Wynn, Denné Reed, Denis Geraads, René Bobe, and Hamdallah Béarat. 2011. Tool-marked bones from before the Oldowan change the paradigm. Proceedings of the National Academy of Sciences 108:E116. [DRB]

McPherron, Shannon P., Zeresenay Alemseged, Curtis W. Marean, Jonathan G. Wynn, Denné Reed, Denis Geraads, René Bobe, and Hamdallah A. Béara. 2010. Evidence for stone-tool-assisted consumption of animal tissues before 3.39 million years ago at Dikika, Ethiopia. Nature 466(7308):857-860.

Mercader, Julio, Melissa Panger, and Christophe Boesch. 2002. Excavation of a chimpanzee stone tool site in the African rainforest. Science 296(5572):14521455.

Merritt, S. R. 2015. Cut mark cluster geometry and equifinality in replicated Early Stone Age butchery. International Journal of Osteoarchaeology 26:585-598.

Mitani, J. C., and D. P. Watts. 1999. Demographic influences on the hunting behavior of chimpanzees. American Journal of Physical Anthropology 9:439-454. [DRB]

Mithen, S. J. 2005. The singing Neanderthal: the origins of music, language, mind and body. London: Weidenfield \& Nicholson. [JJS]

Mora, Rafael, and Ignacio de la Torre. 2005. Percussion tools in Olduvai Beds I and II (Tanzania): implications for early human activities. Lournal of Anthropological Archaeology 24(2):179-192.

Morin, E. 2007. Fat composition and Nunamiut decision-making: a new look at the marrow and bone grease indices. Iournal of Archaeological Science 34:69-82. 
Mulcahy, Nicholas J., and Josep Call. 2006. Apes save tools for future use. Science 312(5776):1038-1040.

Murphy, Suzanne P., and Lindsay H. Allen. 2003. Nutritional importance of animal source foods. Journal of Nutrition 133(11):3932S-3935S.

Njau, Jackson. 2012. Reading Pliocene bones. Science 336(6077):46-47.

Njau, Jackson K., and William Gilbert. 2016. Standardizing terms for crocodileinduced bite marks on bone surfaces in light of the frequent bone modification equifinality found to result from crocodile feeding behavior, stone tool modification, and trampling. Forensic Osteology Occasional Publications 3:113. [MP]

Oliver, J. S. 1994. Estimates of hominid and carnivore involvement in the Flk Zinjanthropus fossil assemblage: some socioecological implications. Journa of Human Evolution 27:267-294. [DRB]

Otárola-Castillo, E., M. Torquato, H. Hawkins, E. James, J. Harris, C. W. Marean, S. P. McPherron, and J. C. Thompson. 2018. Differentiating between cutting actions on bone using 3D geometric morphometrics and Bayesian analyses with implications to human evolution. Iournal of Archaeological Science 89:56-67.

Panger, M. A., A. S. Brooks, B. G. Richmond, and B. Wood. 2002. Older than the Oldowan? rethinking the emergence of hominin tool use. Evolutionary Anthropology 11(6):235-245.

Pante, M. C., M. Muttart, T. Keevil, R. J. Blumenschine, J. K. Njau, and S. M. Merritt. 2017. A new high-resolution 3-D quantitative method for identifying bone surface modifications with implications for the Early Stone Age archaeological record. Journal of Human Evolution 102:1-11. [MP]

Pante, Michael C., Robert S. Scott, Robert J. Blumenschine, and Salvatore D. Capaldo. 2015. Revalidation of bone surface modification models for inferring fossil hominin and carnivore feeding interactions. Quaternary International 355:164-168.

Parkinson, Jennifer A., Thomas Plummer, and Adam Hartstone-Rose. 2015. Characterizing felid tooth marking and gross bone damage patterns using GIS image analysis: an experimental feeding study with large felids. Lournal of Human Evolution 80:114-134.

Plummer, T. W., and L. C. Bishop. 1994. Hominid paleoecology at Olduvai Gorge, Tanzania as indicated by antelope remains. Journal of Human Evolution 27:47-75. [DRB]

Plummer, Thomas W., Peter W. Ditchfield, Laura C. Bishop, John D. Kingston, Joseph V. Ferraro, David R. Braun, Fritz Hertel, and Richard Potts. 2009. Oldest evidence of toolmaking hominins in a grasslanddominated ecosystem. PLoS ONE 4(9):e7199.

Pobiner, Briana L. 2015. New actualistic data on the ecology and energetics of hominin scavenging opportunities. Iournal of Human Evolution 80:1-16.

Potts, Richard. 1989. Olorgesailie: new excavations and findings in Early and Middle Pleistocene contexts, southern Kenya Rift Valley. Iournal of Human Evolution 18:477-484. [DRB]

. 2013. Hominin evolution in settings of strong environmental variability. Quaternary Science Reviews 73:1-13.

Potts, Richard, and J. Tyler Faith. 2015. Alternating high and low climate var iability: the context of natural selection and speciation in Plio-Pleistocene hominin evolution. Journal of Human Evolution 87:5-20.

Prieto, J. 2013. Hunting and vertebrate consumption in wild bearded capuchin monkeys (Sapajus libidinosus) from Fazenda Boa Vista, Brazil: an evolutionary approach. Master's thesis, Universidade de Coimbra. [EV]

Proffitt, Tomos, Lydia V. Luncz, Tiago Falótico, Eduardo B. Ottoni, Ignacio de la Torre, and Michael Haslam. 2016. Wild monkeys flake stone tools. Nature 539:85-88

Pruetz, Jill D., and Paco Bertolani. 2007. Savanna chimpanzees, Pan troglodytes verus, hunt with tools. Current Biology 17(5):412-417.

Ragir, Sonia, Martin Rosenberg, and Philip Tierno. 2000. Gut morphology and the avoidance of carrion among chimpanzees, baboons, and early hominids. Journal of Anthropological Research 56(4):477-512.

Rezek, Z., S. Lin, R. Iovita, and H. L. Dibble. 2011. The relative effects of core surface morphology on flake shape and other attributes. Lournal of Archaeological Science 38:1346-1359.

Ripple, William J., James A. Estes, Robert L. Beschta, Christopher C. Wilmers, Euan G. Ritchie, Mark Hebblewhite, Joel Berger, et al. 2014. Status and ecological effects of the world's largest carnivores. Science 343(6167):1241484.

Robinson, J. R., J. Rowan, C. J. Campisano, J. G. Wynn, and K. E. Reed. 2017. Late Pliocene environmental change during the transition from Australopithecus to Homo. Nature Ecology and Evolution 1(6):0159. [DRB]

Roffman, Itai, Sue Savage-Rumbaugh, Elizabeth Rubert-Pugh, André Stadler, Avraham Ronen, and Eviatar Nevo. 2015. Preparation and use of varied natural tools for extractive foraging by bonobos (Pan paniscus). American Journal of Physical Anthropology 158(1):78-91.

Rogers, Michael J., John W. K. Harris, and Craig S. Feibel. 1994. Changing patterns of land use by Plio-Pleistocene hominids in the Lake Turkana Basin. Journal of Human Evolution 27(1-3):139-158. [DRB]

Rogers, Michael J., and Sileshi Semaw. 2009. From nothing to something: the appearance and context of the earliest archaeological record. In Sourcebook of paleolithic transitions. M. Camps and P. Chauhan, eds. Pp. 155-171. New York: Springer.

Rosell, Jordi, Ruth Blasco, Gerard Campeny, J Carlos Díez, Rodrigo Alonso Alcalde, Leticia Menéndez, Juan Luis Arsuaga, José M Bermúdez de Castro, and Eudald Carbonell. 2011. Bone as a technological raw material at the Gran Dolina site (Sierra de Atapuerca, Burgos, Spain). Journal of Human Evolution 61(1):125-131.

Rothman, Jessica M., David Raubenheimer, Margaret A. H. Bryer, Maressa Takahashi, and Christopher C. Gilbert. 2014. Nutritional contributions of insects to primate diets: implications for primate evolution. Journal of Human Evolution 71:59-69.

Rowan, John, and Kaye Reed. 2015. The paleoclimatic record and PlioPleistocene paleoenvironments. In Handbook of paleoanthropology. W. Henke and I. Tattersall, eds. Pp. 465-491. New York: Springer.

Sahle, Yonatan, Sireen El Zaatari, and Tim D. White. 2017. Hominid butchers and biting crocodiles in the African Plio-Pleistocene. Proceedings of the National Academy of Sciences 114(50):13164-13169.

Sayers, K., and C. O. Lovejoy. 2014. Blood, bulbs, and bunodonts: on evolutionary ecology and the diets of Ardipithecus, Australopithecus, and early Homo. Quarterly Review of Biology 89(4):319-357.

Selvaggio, M. M. 1998. Evidence for a three-stage sequence of hominid and carnivore involvement with long bones at FLK Zinjanthropus, Olduvai Gorge, Tanzania. Journal of Archaeological Science 25:191-202. [MP]

Shea, John J. 2017a. Occasional, obligatory, and habitual stone tool use in hominin evolution. Evolutionary Anthropology 26(5):200-217.

Shea, John J. 2017b. Stone tools in human evolution: behavioral differences among technological primates. New York: Cambridge University Press. [JJS]

Shott, M. J., and P. Sillitoe. 2005. Use life and curation in New Guinea experimental used flakes. Iournal of Archaeological Science 32:653-663. [DRB]

Smith, Alex R., Rachel N. Carmody, Rachel J. Dutton, and Richard W. Wrangham. 2015. The significance of cooking for early hominin scavenging. Journal of Human Evolution 84:62-70.

Speth, John D. 1989. Early hominid hunting and scavenging: the role of meat as an energy source. Journal of Human Evolution 18(4):329-343.

2010. Were big-game hunters targeting fat? In The paleoanthropology and archaeology of big-game hunting. John D. Speth, ed. Pp. 87-107. New York: Springer

Sponheimer, Matt, Zeresenay Alemseged, Thure E. Cerling, Frederick E. Grine, William H. Kimbel, Meave G. Leakey, Julia A. Lee-Thorp, et al. 2013. Isotopic evidence of early hominin diets. Proceedings of the National Academy of Sciences 110(26):10513-10518.

Stammati, M., G. Sabbatini, and E. Visalberghi. 2008. An experimental analysis of ingestion rates in an omnivorous species. American Journal of Primatology 70(5):510-513. [EV]

Stanford, Craig B. 1995. Chimpanzee hunting behavior and human evolution. American Scientist 83:256-261.

. 1996. The hunting ecology of wild chimpanzees: implications for the evolutionary ecology of Pliocene hominids. American Anthropologist 98(1):96-113.

. 1998. Chimpanzee and red colobus: the ecology of predator and prey. Cambridge, MA: Harvard University Press. [RW]

. 2001. A comparison of social meat-foraging by chimpanzees and human foragers. In Meat-eating and human evolution. C. B. Stanford and H. T. Bunn, eds. Pp. 122-140. Oxford: Oxford University Press.

2012. Chimpanzees and the behavior of Ardipithecus ramidus. Annual Review of Anthropology 41:139-149.

Stanford, Craig B., and Henry T. Bunn. 2001. Meat eating and human evolution. New York: Oxford University Press.

Stewart, K. M. 1994. Early hominid utilization of fish resources and implications for seasonality and behavior. Lournal of Human Evolution 27:229245. [DRB]

Stewart, K. M., and D. Gifford-Gonzalez. 1994. An ethnoarchaeological contribution to identifying hominid fish processing sites. Journal of Archaeological Science 21:237-248. [DRB] 
Stout, Dietrich, Sileshi Semaw, Michael J. Rogers, and Dominique Cauche. 2010. Technological variation in the earliest Oldowan from Gona, Afar Ethiopia. Journal of Human Evolution 58(6):474-491.

Surbeck, Martin, and Gottfried Hohmann. 2008. Primate hunting by bonobos at LuiKotale, Salonga National Park. Current Biology 18(19):R906-R907.

Tappen, M. 2001. Deconstructing the Serengeti. In Meat eating and human evolution. C. B. Stanford and H. T. Bunn, eds. Pp. 13-31. Oxford: Oxford University Press.

Tennie, Claudio, Robert C. O’Malley, and Ian C. Gilby. 2014. Why do chimpanzees hunt? considering the benefits and costs of acquiring and consuming vertebrate versus invertebrate prey. Journal of Human Evolution 71:38-45.

Thompson, J., S. Lansing, C. W. Marean, S. McPherron, and Z. Alemseged. 2011. Experimental definition of bone surface signatures from natural unmodified stones and implications for early hominin subsistence. PaleoAnthropology A38. [DRB]

Thompson, J. C., William H. Kimbel, Erella Hovers, and C. W. Marean. 2016. New approaches to taphonomy and field survey of fossils across the Hadar paleo-landscape at 3.3 Ma. Abstract presented at the Paleoanthropology Society meeting, Atlanta, GA, April.

Thompson, J. C., S. P. McPherron, René Bobe, D. Reed, W. A. Barr, J. Wynn, C. W. Marean, D. Geraads, and Z. Alemseged. 2015. Taphonomy of fossils from the hominin-bearing deposits at Dikika, Ethiopia. Journal of Human Evolution 86:112-135.

Toth, N. 2017. Revised taphonomic perspective on African Plio-Pleistocene fauna. Proceedings of the National Academy of Sciences 114(50):13066-13077. [DRB]

Treves, Adrian, and L. Naughton-Treves. 1999. Risk and opportunity for humans coexisting with large carnivores. Iournal of Human Evolution 36(3):275-282.

Turner, A. 1999. Evolution in African Plio-Pleistocene mammalian fauna: correlation and causation. In African biogeography, climate change, and early human evolution. Timothy G. Bromage and Friedemann Schrenk, eds. Pp. 76-87. Oxford: Oxford University Press.

Ugan, Andrew. 2005. Does size matter? body size, mass collecting, and their implications for understanding prehistoric foraging behavior. American Antiquity 70(1):75-89.

Ungar, P. S., F. E. Grine, and M. F. Teaford. 2006. Diet in early Homo: a review of the evidence and a new model of adaptive versatility. Annual Review of Anthropology 35:209-228. [DRB]

van der Merwe, Nikolaas J., J. Francis Thackeray, Julia A. Lee-Thorp, and Julie Luyt. 2003. The carbon isotope ecology and diet of Australopithecus africanus at Sterkfontein, South Africa. Journal of Human Evolution 44(5):581597.

Villmoare, Brian, William H. Kimbel, Chalachew Seyoum, Christopher J. Campisano, Erin N. DiMaggio, John Rowan, David R. Braun, J Ramón Arrowsmith, and Kaye E. Reed. 2015. Early Homo at $2.8 \mathrm{Ma}$ from LediGeraru, Afar, Ethiopia. Science 347(6228):1352-1355.

Visalberghi, E., and A. Albani. 2014. The bearded capuchin monkeys of Fazenda Boa Vista. DVD. [EV]

Visalberghi, E., G. Sabbatini, M. Stammati, and E. Addessi. 2003. Preferences towards novel foods in Cebus apella: the role of nutrients and social influences. Physiology and Behavior 80(2-3):341-349. [EV]

Visalberghi, E., N. Spagnoletti, E. D. Ramos da Silva, F. R. D. Andrade, E. Ottoni, P. Izar, and D. Fragaszy. 2009. Distribution of potential suitable hammers and transport of hammer tools and nuts by wild capuchin monkeys. Primates 50:95-104.
Visalberghi, Elisabetta, Elsa Addessi, Valentina Truppa, Noemi Spagnoletti, Eduardo Ottoni, Patricia Izar, and Dorothy Fragaszy. 2009. Selection of effective stone tools by wild bearded capuchin monkeys. Current Biology 19(3):213-217.

Ward, Carol V., William H. Kimbel, and Donald C. Johanson. 2011. Complete fourth metatarsal and arches in the foot of Australopithecus afarensis. Science 331(6018):750-753.

Watts, David P. 2008. Scavenging by chimpanzees at Ngogo and the relevance of chimpanzee scavenging to early hominin behavioral ecology. Iournal of Human Evolution 54(1):125-133.

Watts, David P., and John C. Mitani. 2002. Hunting behavior of chimpanzees at Ngogo, Kibale national Park, Uganda. International Journal of Primatology 23(1):1-28.

Werdelin, Lars. 1999. Pachycrocuta (hyaenids) from the Pliocene of East Africa. Paläontologische Zeitschrift 73(1-2):157-165.

Werdelin, Lars, and Margaret E. Lewis. 2005. Plio-Pleistocene Carnivora of eastern Africa: species richness and turnover patterns. Zoological Journal of the Linnean Society 144(2):121-144.

Werdelin, Lars, and Margaret E. Lewis. 2013. Temporal change in functional richness and evenness in the eastern African Plio-Pleistocene carnivoran guild. PLOS ONE 8(3):e57944. [DRB, LW]

Werdelin, Lars, Margaret E. Lewis, and Yohannes Haile-Selassie. 2014. MidPliocene carnivora from the Woranso-Mille area, Afar region, Ethiopia. Lournal of Mammalian Evolution 21(3):331-347. [DRB]

Werdelin, Lars, and Nikos Solounias. 1991. The Hyaenidae: taxonomy, systematics and evolution. Fossils and Strata 30:1-104. [LW]

White, Tim D, Stanley H Ambrose, Gen Suwa, Denise F Su, David DeGusta, Raymond L Bernor, Jean-Renaud Boisserie, Michel Brunet, Eric Delson, and Stephen Frost. 2009. Macrovertebrate paleontology and the Pliocene habitat of Ardipithecus ramidus. Science 326(5949):67-93.

Whiten, Andrew. 2015. Experimental studies illuminate the cultural transmission of percussive technologies in Homo and Pan. Philosophical Transactions of the Roval Society of London B: Biological Sciences 370(1682): 20140359.

Wilfried, Ebang Ella Ghislain, and Juichi Yamagiwa. 2014. Use of tool sets by chimpanzees for multiple purposes in Moukalaba-Doudou National Park, Gabon. Primates 55(4):467-472.

Wilson, Michael L., C. Boesch, Barbara Fruth, Takeshi Furuichi, I. C. Gilby, Chie Hashimoto, Catherine Hobaiter, et al. 2014. Lethal aggression in Pan is better explained by adaptive strategies than human impacts. Nature 513:414-417. [RW]

Wrangham, Richard. 2017. Control of fire in the Paleolithic: evaluating the cooking hypothesis. Current Anthropology 58(16):S303-S313. [RW]

Wynn, Jonathan G., Matt Sponheimer, William H. Kimbel, Zeresenay Alemseged, Kaye Reed, Zelalem K. Bedaso, and Jessica N. Wilson. 2013. Diet of Australopithecus afarensis from the Pliocene Hadar Formation, Ethiopia. Proceedings of the National Academy of Sciences 110(26):1049510500 .

Yravedra, José, Julia Aramendi, Miguel Ángel Maté-González, Lloyd Austin Courtenay, and Diego González-Aguilera. 2018. Differentiating percussion pits and carnivore tooth pits using $3 \mathrm{D}$ reconstructions and geometric morphometrics. PLoS ONE 13(3):e0194324.

Zihlman, Adrienne L. 2012. The real females of human evolution. Evolutionary Anthropology 21(6):270-276.

Zink, Katherine D., and Daniel E. Lieberman. 2016. Impact of meat and Lower Palaeolithic food processing techniques on chewing in humans. Nature 531:500-503. 